\title{
Miejsce życia i człowieka w przyrodzie. Obrona tezy antropocentrycznej
}

\section{Wprowadzenie}

Kwestyą, najbardziej obchodzącą ludzkość, przed którą, można powiedzieć, wszystkie inne ustępują - jest bezwątpienia określenie stanowiska, jakie człowiek w przyrodzie zajmuje a zarazem i wykazanie jego stosunków do wszechświata. ${ }^{1}$

Przez setki lat odpowiedzi na „,najbardziej obchodzące ludzkość” pytanie o którym w powyższym cytacie pisał Thomas Huxley — udzielał tradycyjny, teleologiczny i antropocentryczny układ odniesienia. Jednak po rewolucji kopernikańskiej, a zwłaszcza po opublikowaniu O powstawaniu gatunków Karola Darwina, ten tradycyjny układ odniesienia stawał się coraz trudniejszy do obrony. Ludzkość, jak się wydawało, nie zajmuje wyjątkowego miejsca w przyrodzie. Staram się jednak przekonywać, że odkrycia poczynione w chemii i biochemii w wiekach dziewiętnastym i dwudziestym, a także w dwudziestowiecznej kosmologii, fizyce fundamentalnej i fizjologii porównawczej, na nowo otworzyły „wielką debatę". Zapewniły one bowiem intrygujące, nowe poparcie staremu i rzekomo przestarzałemu paradygmatowi antropocentrycznemu.

* Michael J. Denton, „The Place of Life and Man in Nature: Defending the Anthropocentric Thesis", BIO-Complexity 2013, no. 1, s. 1-15, http://bio-complexity.org/ojs/index.php/main/arti cle/view/BIO-C.2013.1/BIO-C.2013.1 (26.10.2015), doi: 10.5048/BIO-C.2013.1. Za zgodą Autora z języka angielskiego przełożył: Dariusz SAGAN.

${ }^{1}$ T.H. Huxley, Stanowisko czlowieka w przyrodzie. Trzy rozprawy, przeł. Stefan Żaryn, Nakładem Redakcji Przeglądu Tygodniowego, Warszawa 1874, s. 54. 
Jednym z pierwszych autorów, który zwrócił uwagę na te nowe świadectwa, był, jak na ironię, Alfred Russel Wallace, który, obok Darwina, uznawany jest za współtwórcę teorii ewolucji drogą doboru naturalnego. Świadectwa te opisał w książce World of Life [Świat życia], opublikowanej w 1910 roku, czyli nieco ponad sto lat temu. ${ }^{2}$ Już trzy lata później, w roku 1913, Lawrence Henderson przedstawił pierwszą szczegółową obronę paradygmatu antropocentrycznego w swym klasycznym dziele The Fitness of the Environment [Dostosowanie środowiska] (dalej nazywanym skrótowo The Fitness). ${ }^{3}$ Henderson twierdził, że zespót podstawowych substancji biochemicznych, które wchodzą w skład życia ziemskiego, cechuje się unikatowym synergicznym dostosowaniem do życia, jakie rozwinęło się tu na Ziemi. Jest to praca klasyczna, której poświęcę wiele uwagi w tym artykule.

Jak podkreślał Henderson, koncepcja „,dostosowania środowiska” jest zupełnie odmienna od darwinowskiej koncepcji ,dostosowania organizmu”. ${ }^{4}$ Według Darwina dostosowanie organizmu to wynik czysto naturalnych, nieteleologicznych procesów, które stopniowo dostosowują lub kształtują organizmy żywe $d o$ konkretnych środowisk drogą przyrostowych kroczków. Jednak żaden taki mechanizm nie może wytłumaczyć dostosowania środowiska do życia. Henderson komentuje: „Dobór naturalny kształtuje jedynie organizm, zaś środowisko przekształca tylko w sposób drugorzędny, nie zmieniając istotnie podstawowego dostosowania środowiskowego. Ten ostatni składnik dostosowania, poprzedzający adaptacje [...] bynajmniej nie jest wyjaśniony [przez dobór naturalny]". ${ }^{5}$ Innymi słowy, pojęcie dostosowania zostało zastosowane przez Hendersona do środowiska, nie zaś do organizmów. Argumentował on, że samo środowisko jest „dostosowane” do życia biologicznego, co znaczy, że właściwości środowiska są wyjątkowo dobrze dopasowane do istot żywych. W całym tym artykule poję-

\footnotetext{
${ }^{2}$ Por. M.A. Flannery, W.A. Dembski, and A.R. Wallace, Alfred Russel Wallace's Theory of Intelligent Evolution: How Wallace's World of Life Challenged Darwinism, with an abridged version of The World of Life, Erasmus Press, Riesel, Texas 2008, rozdz. 7.

${ }^{3}$ Por. L. Henderson, The Fitness of the Environment: An Inquiry into the Biological Significance of the Properties of Matter, Macmillan Co., New York 1913.

${ }^{4}$ Por. Henderson, The Fitness of the Environment..., s. v-ix, rozdz. 8.

${ }^{5}$ Henderson, The Fitness of the Environment..., s. 274-275.
} 
cie „dostosowania” będzie używane w znaczeniu, w jakim stosował je Henderson, czyli w sensie dopasowania środowiska do znanego nam życia. Należy odróżnić to znaczenie od znacznie węższego sensu „dostosowania” stosowanego przez biologów ewolucyjnych — nie można tych znaczeń mylić.

Na początku należy też zauważyć, że - logicznie rzecz biorąc - kosmos musi być dostosowany do życia na Ziemi (życia ziemskiego) oraz do istnienia człowieka. W przeciwnym razie nie byłoby nas tutaj i nie moglibyśmy tego zaobserwować, a także zadać pytania Huxleya. Jeśli twierdzimy, że kosmos jest dostosowany do istnienia człowieka, biorąc za podstawę wyłącznie fakt naszego istnienia, to zasadniczo jest to twierdzenie trywialne, na co wskazuje Carl Sagan:

Jest coś zdumiewająco zawężającego w sformułowaniu zasady antropicznej. Tak, to prawda, że tylko pewne prawa i pewne wartości stałych przyrody umożliwiają powstanie życia w znanej nam postaci. Niemniej zasadniczo te same prawa i stałe fizyczne warunkują powstanie skał. Dlaczegóż więc nie przyjąć, że Wszechświat został tak pomyślany, by pewnego dnia pojawiły się w nim skały? I mówić o silnej i słabej zasadzie litycznej? ${ }^{6}$

Przyjęcie radykalnego poglądu, że Wszechświat jest zaprojektowany dla naszego istnienia, idei zawartej w tradycyjnym antropocentrycznym układzie odniesienia, wymaga zatem kosmosu, w którym prawa przyrody są wyjątkowo dostosowane do istnienia życia ziemskiego oraz biologicznych istot podobnych do współczesnych ludzi, i zarazem kosmosu wykluczającego wszystkie pozostałe alternatywy, od egzotycznych biochemii po kosmitów rodem z filmu Star Trek.

W artykule dokonuję przeglądu niektórych argumentów przedstawionych przez Hendersona i pokazuję, że po stu latach ogromnego rozwoju wiedzy biologicznej jego poglądy zostały w pełni potwierdzone. Jak argumentowałem w książce Nature's Destiny [Przeznaczenie przyrody], ${ }^{7}$ aktualne dane empi-

${ }^{6}$ C. SAGAN, Błękitna kropka. Człowiek i jego przyszłość w kosmosie, przeł. Marek Krośniak, Na Ścieżkach Nauki, Prószyński i S-ka, Warszawa 1996, s. 61.

${ }^{7}$ Por. M.J. Denton, Nature's Destiny: How the Laws of Biology Reveal Purpose in the Universe, Free Press, New York 1998. 
ryczne bardzo dobitne wskazują, że kosmos rzeczywiście jest wyjątkowo dostosowany do życia ziemskiego i do istot przypominających współczesnych ludzi.

To złożone zagadnienie. W artykule przeznaczonym do publikacji w czasopiśmie koniecznością jest ograniczenie objętości tekstu, które wiąże się z tym, że wiele danych empirycznych, także część tych najbardziej intrygujących, należy pominąc lub jedynie krótko wspomnieć. Dostosowaniem cechują się także hydrosfera i atmosfera, geofizyka Ziemi (w tym procesy tektoniczne i hydrolityczne) oraz fizyczny projekt ciała człowieka. Bardziej wyczerpujące omówienie można znaleźć w książce Nature's Destiny. ${ }^{8}$

\section{Dostosowanie przyrody do życia ziemskiego}

W The Fitness Henderson argumentował, że podstawowe składniki chemiczne wszystkich organizmów żywych na Ziemi — woda, dwutlenek węgla, tlen i związki organiczne - składają się na witalny zespót, który w całości cechuje się unikatowym, wzajemnym lub synergicznym dostosowaniem do tworzenia układów ożywionych: ${ }^{9}$

\footnotetext{
${ }^{8}$ Por. Denton, Nature's Destiny....

${ }^{9}$ Henderson zdefiniował układy ożywione (por. Henderson, The Fitness of the Environment..., s. 32-35) jako trwałe fizykochemiczne mechanizmy o wysokim stopniu złożoności, zdolne do autoregulacji i homeostazy dzięki procesom metabolicznym, które obejmują wymianę energii i materii z otoczeniem. Od czasów Hendersona wielu innych autorów formułowało definicje życia i organizmów (por. D.L. AвEL, „Is Life Unique?”, Life 2011, vol. 2, s. 106-134, doi: 10.33 90/life2010106), które obejmują te same podstawowe elementy, jakie wskazywał Henderson (por. N.R. PACE, „Special Feature: The Universal Nature of Biochemistry”, Proceedings of the National Academy of Sciences USA 2001, vol. 98, s. 805-808, doi: 10.1073/pnas.98.3.805; D. Schulze-MAKUCH and L.N. IRwIN, „The Prospect of Alien Life in Exotic Forms on Other Worlds”, Naturwissenschaften 2006, vol. 93, s. 155 [155-172], doi: 10.1007/s00114-005-0078-6; A. BAross, S.A. Benner, G.D. Cody, S.D. Copley, N.R. Pace, J.H. Scott, and R. Shapiro, The Limits of Organic Life in Planetary Systems, National Academies Press, Washington, DC. 2007; J. Gale, Astrobiology of Earth: The Emergence, Evolution, and Future of Life on a Planet in Turmoil, Oxford University Press, Oxford 2009, rozdz. 1; L.N. Irwin and D. Schulze-Makuch, Cosmic Biology: How Life Could Evolve on Other Worlds, Praxis, Springer, published in association with Praxis Pub., New York 2010 (2011 edition), s. 42; K.W. Plaxco and M. Gross, Astrobiology: A Brief Introduction, Johns Hopkins University Press, Baltimore 2011, rozdz. 1).
} 
Dostosowanie środowiska jest wynikiem cech, które tworzą szereg maksimów — unikatowe lub niemal unikatowe właściwości wody, kwasu węglowego, związków węgla, wodoru i tlenu [...] tak liczne, tak zróżnicowane, niemal tak kompletne pośród wszystkiego, co dotyczy tego problemu, że łącznie bez wątpienia tworzą one najlepsze dostosowanie z możliwych. Żadne inne środowisko składające się z [...] innych znanych pierwiastków [...] nie może mieć [...] tak dużego dostosowania do tworzenia złożoności, trwałości i aktywnego metabolizmu w mechanizmie organicznym, który nazywamy życiem. ${ }^{10}$

Mówiąc prosto, Henderson uważał, że jeśli chcemy utworzyć jakikolwiek typ układu chemicznego, który miałby cechy przypisywane przez nas życiu, to musimy wykorzystać ten witalny zespót: wodę jako macierz oraz organiczne związki węgla umożliwiające budowanie elementów molekularnych. Wskutek tego, według Hendersona, tylko życie ziemskie — forma życia istniejącego na Ziemi — jest zapisane w porządku naturalnym.

\section{Węgiel}

Henderson, chcąc bronić swojej tezy, systematycznie dokonywał przeglądu większości znanych $\mathrm{w}$ jego czasach właściwości witalnego zespołu. Zgodnie $\mathrm{z}$ jednym z jego kluczowych argumentów węgiel jest wyjątkowy w swojej zdolności do łączenia się z innymi atomami, tworząc niezrównaną ilość związków $\mathrm{z}$ wodorem, tlenem i azotem. ${ }^{11}$ Ten wszechświat chemii organicznej $-\mathrm{z}$ jego ogromną różnorodnością właściwości chemicznych i fizycznych — stanowi właśnie konieczny warunek tworzenia złożonych układów chemicznych. Do dostosowania chemii węgla do życia biochemicznego w wielkiej mierze przyczynia się ponadto ogólna „metastabilność” wiązań węglowych i związana z nią względna łatwość, z jaką układy ożywione mogą je tworzyć i reorganizować. ${ }^{12}$ Tym samym Henderson argumentował, że żaden inny atom poza węglem nie jest nawet w przybliżeniu tak dobrze dostosowany do tworzenia złożonej biochemii życia.

\footnotetext{
${ }^{10}$ Henderson, The Fitness of the Environment..., s. 272.

${ }^{11}$ Por. Henderson, The Fitness of the Environment..., rozdz. 6.

${ }^{12}$ Por. Henderson, The Fitness of the Environment..., s. 220-222, 232-237.
} 
W naszych czasach, sto lat później, nikt nie wątpi w te twierdzenia. W rzeczy samej, od czasów Hendersona wielu badaczy potwierdziło niezrównane dostosowanie atomu węgla do tworzenia złożoności chemicznej i jego znaczenie dla biochemii. ${ }^{13} \mathrm{Na}$ charakterystyczną metastabilność związków węgla zwrócił uwagę Needham, ${ }^{14}$ a jeszcze później Plaxco i Gross. ${ }^{15}$ Ich konkluzja jest następująca:

Ostatecznie równie dobrze mógłby istnieć tylko jeden pierwiastek — węgiel [...] podstawa całego życia na Ziemi - potrafiący utrzymywać złożoną chemię, która jest prawdopodobnie konieczna do utworzenia jakiegokolwiek samopowielającego się ukladu chemicznego. ${ }^{16}$

\section{Woda}

Henderson argumentował też, że woda, jeden z pozostałych podstawowych składników jego witalnego zespotu, jest wyjątkowo dostosowana do pełnienia funkcji macierzy, w ramach której może być tworzona złożona chemia życia. Mówił on o sile wody jako rozpuszczalnika, znacznie większej niż jakiejkolwiek innej pospolitej cieczy. Woda potrafi utrzymywać w roztworze ogromny, niezrównany zakres rozmaitych związków chemicznych. Jej szczególnie wysoka stała dielektryczna ${ }^{17}$ odpowiada za jej zdolność do rozpuszczania niemal wszystkich naładowanych cząsteczek. ${ }^{18}$ Siła wody jako rozpuszczalnika oraz jej względna obojętność chemiczna nadają tej cieczy idealne właściwości do pełnienia roli macierzy układów ożywionych. ${ }^{19}$ Nawiązując do innych elementów

${ }^{13}$ Por. Denton, Nature's Destiny..., rozdz. 5; Irwin and Schulze-Makuch, Cosmic Biology..., rozdz. 2; Plaxco and Gross, Astrobiology..., s. 6-14; A.E. Needham, The Uniqueness of Biological Materials, Pergamon Press, UK 1965.

${ }^{14}$ Por. NeEdham, The Uniqueness of Biological Materials..., rozdz. 3.

${ }^{15}$ Por. Plaxco and Gross, Astrobiology..., s. 7-12.

${ }^{16}$ Plaxco and Gross, Astrobiology..., s. 6.

${ }^{17}$ Por. Henderson, The Fitness of the Environment..., s. 118-125.

${ }^{18}$ Por. Henderson, The Fitness of the Environment..., s. 118-126.

${ }^{19}$ Por. Henderson, The Fitness of the Environment..., s. 111-118; F. Franks, Water: A Comprehensive Treatise. Vol. 1: The Physics and Physical Chemistry of Water, Plenum Press, New 
dostosowania, Henderson wskazywał, że woda bierze udział w dwu kluczowych i wszechobecnych procesach biochemicznych w komórce - hydrolizie (dodawaniu grupy hydroksylowej) i reakcji odwrotnej, to jest kondensacji - które biorą udział $\mathrm{w}$ metabolizmie niemal wszystkich związków organicznych. ${ }^{20}$ Omawiał również rolę, jaką jej unikatowe właściwości termiczne odgrywają w ochronie organizmów przed nagłymi zmianami temperatury oraz w stabilizowaniu i łagodzeniu globalnego klimatu. ${ }^{21}$

Odkrycia dokonane od czasów Hendersona dodatkowo potwierdziły pogląd, że woda jest szczególnie dostosowana do życia opartego na węglu. Jednego ważnego odkrycia dokonano dopiero po molekularnej rewolucji w biologii w połowie dwudziestego wieku, gdy objaśniono trójwymiarową strukturę podstawowych makrocząsteczek w komórce. Okazuje się, że zakres temperatury, w jakim woda utrzymuje stan ciekły $-0-100^{\circ} \mathrm{C}$ - pokrywa się z zakresem temperatury, w jakiem układy biochemiczne mogą łatwo manipulować wiązaniami chemicznymi. ${ }^{22}$ Dotyczy to zarówno węglowych wiązań kowalencyjnych (silnych wiązań między atomami biorących udział w wymianie elektronów), jak i wiązań słabych (wiązań wodorowych i wiązań elektrostatycznych, które utrzy mują trójwymiarowe struktury makrocząsteczek biologicznych). Inne nowe odkrycie dotyczy tak zwanego efektu hydrofobowego, którego główną przyczyną jest wysoka stała dielektryczna wody. Efekt hydrofobowy odgrywa istotną rolę w zwijaniu białek i formowaniu błony komórkowej, zmuszając nienaładowane cząsteczki, na przykład lipidy, do tworzenia kompleksów z zamkniętym dostępem dla wody. ${ }^{23}$ Od czasów Hendersona stało się także jasne, że woda jest wyjątkowo dostosowana do przewodności protonów, ${ }^{24}$ procesu kluczowego dla ca-

York 1972, s. 20.

${ }^{20}$ Por. Henderson, The Fitness of the Environment..., s. 232-237.

${ }^{21}$ Por. Henderson, The Fitness of the Environment..., s. 82-110.

${ }^{22}$ Por. Denton, Nature's Destiny..., s. 112-116.

${ }^{23}$ Por. N.T. Southall, K.A. Dill, and A.D.J. Haymet, „A View of the Hydrophobic Effect”, The Journal of Physical Chemistry B 2002, vol. 106, s. 521-533, doi: 10.1021/jp015514e.

${ }^{24}$ Por. H.J. Morowitz, Cosmic Joy and Local Pain: Musings of a Mystic Scientist, Scribner, New York 1987, s. 152-154. 
łego życia, który — jak obecnie wiadomo - odgrywa podstawową rolę w przepływach energii biologicznej. ${ }^{25}$

Trudno dziś znaleźć zaznajomionego z faktami autora, który kwestionowałby wniosek Hendersona, że żadna substancja nie może równać się z wodą w zakresie jej dostosowania do bycia milieu intérieur życia opartego na węglu. Echa twierdzenia Hendersona znajdujemy w słowach Plaxco i Grossa: „Zdolność wody do tworzenia podstawy biochemii może być wyjątkowa [...] żadna inna ciecz nie ma nawet ułamka korzystnych cech wody [...] Życie kategorycznie wymaga ciekłego rozpuszczalnika, a zdecydowanie najlepszym takim rozpuszczalnikiem jest woda". ${ }^{26}$

\section{Dwutlenek węgla}

Kolejnym elementem witalnego zespotu jest dwutlenek węgla $\left(\mathrm{CO}_{2}\right)$. Henderson wskazywał, że $\mathrm{CO}_{2}$ jest nieszkodliwym gazem rozpuszczalnym w wodzie, a więc obecnym w biosferze wszędzie tam, gdzie występuje woda. ${ }^{27}$ Argumentował on, że jeśli woda stanowi macierz życia, to $\mathrm{CO}_{2}$ jest merkuriuszem życia, który rozprowadza kluczowy atom węgla w całej hydrosferze Ziemi. Jak wyraził się Henderson, „Występuje on powszechnie i cechuje go maksymalna mobilność". ${ }^{28}$ Nie znamy żadnego innego związku węgla, który mógłby w taki sposób rozprowadzać węgiel w całej biosferze. Needham komentuje: „Należy podkreślać, że jego gazowa postać jest korzystna, ponieważ jest on jednym z niewielu gazowych tlenków w zwykłych temperaturach". ${ }^{29}$ Henderson nawiązuje też do faktu, że gdy $\mathrm{CO}_{2}$ rozpuszcza się w wodzie, przekształcany jest

\footnotetext{
${ }^{25} \mathrm{~W}$ dwudziestym wieku odkryto wiele innych elementów dostosowania wody (por. DenTon, Nature's Destiny...; FranKs, Water...). Przykładowo wyjątkowe termiczne właściwości wody wspomagają cyrkulację atmosferyczną i oceaniczną, jak również łagodzenie klimatu, o czym szczegółowo traktują standardowe publikacje w zakresie oceanografii (por. T. GARRISON, Oceanography: An Invitation to Marine Science, 7th ed., Brooks/Cole, Cengage Learning, Belmont, California 2010).

${ }^{26}$ Plaxco and Gross, Astrobiology..., s. 14-17.

${ }^{27}$ Por. Henderson, The Fitness of the Environment..., s. 136-139.

${ }^{28}$ Henderson, The Fitness of the Environment..., s. 139.

${ }^{29}$ NeEdham, The Uniqueness of Biological Materials..., s. 35.
} 
w wodorowęglan, który ma doskonałe zdolności buforujące niezbędne do utrzymywania neutralności kwasowo-zasadowej w ciele i w hydrosferze. ${ }^{30} \mathrm{~W}$ rzeczy samej, ma on taką zdolność buforującą w wodzie, że Henderson mógł twierdzić, iż ,poza mechaniką nieba [nie ma] innego przykładu tak wielkiej dokładności w naturalnej regulacji środowiska". ${ }^{31}$ Tak więc $\mathrm{CO}_{2}$ nie tylko rozprowadza węgiel do wszystkich zakątków hydrosfery, lecz także utrzymuje równowagę kwasowo-zasadową, tworząc zrównoważone środowisko wodne, w którym węgiel przenoszony przez $\mathrm{CO}_{2}$ może stać się częścią układów ożywionych. $\mathrm{CO}_{2}$, w nie mniejszym stopniu niż woda, jest zatem wyjątkowo dostosowany do życia opartego na węglu.

\section{Tlen}

Dostosowaniem cechuje się także tlen, składnik dwu najważniejszych elementów zespołu Hendersona, czyli wody $\left(\mathrm{H}_{2} \mathrm{O}\right)$ i $\mathrm{CO}_{2}$, i jeden z kluczowych atomowych cegiełek budulcowych związków organicznych. Szczególne znaczenie ma to, że utlenianie, zwłaszcza węgla i wodoru, dostarcza więcej energii niż niemal wszystkie inne typy reakcji chemicznych. ${ }^{32}$ Dla Hendersona było to jedno z „najdobitniejszych świadectw” wyjątkowego dostosowania chemii węgla do życia. Wskazywał, że „Te same zmiany chemiczne, które z wielu innych powodów wydają się najlepiej dostosowane do przeobrażenia się w procesy fizjologiczne, okazują się również tymi, które mogą zmienić największy napływ energii w strumień życia". ${ }^{33}$ Dziś nikt nie ma wątpliwości, że proces utleniania jest wyjątkowo dobrym źródłem energii. W istocie astrobiologowie poszukują obecnie tlenu w atmosferach planet pozasłonecznych, traktując go jako ślad wskazujący na możliwość obecności zaawansowanych form życia. Powszechnie uznaje się, że tylko utlenianie dostarcza dostatecznej ilości energii dla wysokiego tem-

\footnotetext{
${ }^{30}$ Por. Henderson, The Fitness of the Environment..., rozdz. 4.

${ }^{31}$ Henderson, The Fitness of the Environment..., s. 153.

${ }^{32}$ Por. Henderson, The Fitness of the Environment..., s. 243-248. Jest to fakt, który - jak pokażę - ma kluczowe znaczenie dla zaawansowanych, metabolicznie aktywnych organizmów, których istnienie jest $\mathrm{w}$ dużej mierze zależne od energii utleniania.

${ }^{33}$ Henderson, The Fitness of the Environment..., s. 247.
} 
pa metabolizmu, który jest konieczny — jak się zakłada — w przypadku zaawansowanych form życia opartego na węglu. ${ }^{34}$

Henderson podsumowuje swój argument następująco: „Dostosowanie wody, kwasu węglowego i trzech pierwiastków [wodoru, węgla i tlenu] tworzy unikatowy zespół dostosowania do mechanizmu organicznego [...] Związki te w niczym nie ustępują $[\ldots]$ innym związkom $[\ldots]$ nie odkryto [...] ani jednej ułomności podstawowych składników”. ${ }^{35}$ The Fitness kończy on słowami: „Biolog może teraz słusznie twierdzić, że Wszechświat w swojej istocie jest biocentryczny".

\section{Nowe świadectwa: subtelne zestrojenie kosmosu}

Od czasów Hendersona liczne odkrycia w różnych dziedzinach dodatkowo wsparły pogląd, że przyroda jest biocentryczna. Zapewne najsłynniejsze z nich to tak zwane „kosmiczne koincydencje” i związane z nimi przekonanie, że wartości fundamentalnych stałych fizycznych określających ogólną strukturę Wszechświata i praw przyrody muszą być bardzo bliskie tym, które umożliwiają powstanie Wszechświata przyjaznego życiu. ${ }^{36}$ Kolejnym takim odkryciem było to, że przestrzeń międzygwiazdowa wypełniona jest olbrzymimi ilościami prostych związków organicznych, w tym wieloma podstawowymi cegiełkami budulcowymi ziemskiej biochemii. ${ }^{37}$

\footnotetext{
${ }^{34}$ Por. D.C. Catling, C.R. Glein, K.J. Zahnle, and C.P. McKay, „Why $\mathrm{O}_{2}$ Is Required by Complex Life on Habitable Planets and the Concept of Planetary "Oxygenation Time»", Astrobiology 2005, vol. 5, s. 415-438, doi: 10.1089/ast.2005.5.415.

${ }^{35}$ Henderson, The Fitness of the Environment..., s. 266-267.

${ }^{36}$ Por. P.C.W. Davies, The Accidental Universe, Cambridge University Press, Cambridge, UK 1982; J.D. Barrow and F.J. Tipler, The Anthropic Cosmological Principle, Oxford University Press, Oxford 1988; J. Gribbin i M. Rees, Kosmiczne zbiegi okoliczności. Ciemna materia, ludzkość i antropiczna kosmologia, przeł. Piotr Amsterdamski, Człowiek $i$ Wszechświat, Cyklady, Warszawa 1996.

${ }^{37}$ Por. Denton, Nature's Destiny..., rozdz. 4; PACE, „Special Feature...”; Baross, Benner, Cody, Copley, Pace, Scott, and Shapiro, The Limits of Organic Life..., s. 18; J. Lovelock, Gaja. Nowe spojrzenie na życie na Ziemi, przeł. Marcin Ryszkiewicz, Pejzaże Myśli, Prószyński i S-ka, Warszawa 2003.
} 
Jedną z najczęściej przywoływanych koincydencji jest „szczęśliwy” fakt, że jądrowe rezonanse izotopów ${ }^{12} \mathrm{C} \mathrm{i}{ }^{16} \mathrm{O}$ mają dokładnie taką wartość, jaką muszą mieć, aby węgiel mógł być w ogóle zsyntetyzowany i zgromadzony w danej ilości we wnętrzu gwiazd. ${ }^{38}$ Poziomy energii tych rezonansów gwarantują, że ${ }^{12} \mathrm{C}$ syntetyzowany jest najpierw we wnętrzu gwiazd wskutek zderzeń między jądrami ${ }^{8} \mathrm{Be}$ (berylu) i He (helu) oraz że zsyntetyzowanego węgla nie ubędzie później. Hoyle dokonał tego odkrycia w 1953 roku, gdy współpracował w Caltech z Williamem Fowlerem. ${ }^{39}$ Intrygującym aspektem tego odkrycia jest to, że w tym wypadku Hoyle przyjął za podstawę przewidywanie wypływające z zasady antropicznej. ${ }^{40}$ Oto słynna wypowiedź Hoyle'a:

Gdybyście chcieli wytworzyć węgiel i tlen w mniej więcej równych ilościach w procesie gwiezdnej syntezy jądrowej, to musielibyście ustawić właśnie te dwa poziomy i to dokładnie w tym zakresie, w jakim się one znajdują obecnie [...] Zdroworozsądkowa interpretacja faktów sugeruje, że jakiś super intelekt manipulował warunkami fizycznymi, jak również chemicznymi i biologicznymi, oraz że w przyrodzie nie ma żadnych ślepych sił, o których warto byłoby mówić. ${ }^{41}$

Uznano to nie tylko za ważne odkrycie naukowe, ale także za kolejne świadectwo biocentryczności przyrody. Hoyle zapewne jako pierwszy zauważył, że warunki konieczne do umożliwienia życia opartego na węglu wymagają bardzo wąskiego zakresu podstawowych stałych fizycznych, ale to ustalenie zyskało już powszechną akceptację. ${ }^{42}$ Gdyby te stałe były nawet tylko nieco inne, to we Wszechświecie niemożliwy byłby rozwój materii, struktur astronomicznych lub różnorodności pierwiastków, a tym samym nie byłoby możliwe pojawienie się złożonych układów chemicznych. ${ }^{43}$

\footnotetext{
${ }^{38}$ Por. Barrow and Tipler, The Anthropic Cosmological Principle..., s. 250-255.

${ }^{39}$ Por. F. Hoyle, Galaxies, Nuclei and Quasars, Harper and Row, New York 1966.

${ }^{40}$ Por. F. Hoyle, Mój dom kędy wieją wiatry. Stronice z życia kosmologa, przeł. Marek Krośniak, Na Ścieżkach Nauki, Prószyński i S-ka, Warszawa 2001, s. 285.

${ }^{41}$ Cyt. za: Davies, The Accidental Universe..., s. 118.

${ }^{42}$ Por. DAVIES, The Accidental Universe...; BARROW and TIPLER, The Anthropic Cosmological Principle...; Gribbin i Rees, Kosmiczne zbiegi okoliczności....

${ }^{43}$ Por. Gribbin i Rees, Kosmiczne zbiegi okoliczności....
} 


\section{Nowe świadectwa: ekstremofile}

Kolejnym nowym - od czasów Hendersona - osiągnięciem było odkrycie, że wiele form życia opartego na węglu — ekstremofile — potrafi przetrwać w warunkach bardzo odmiennych od tych, jakie panują na powierzchni Ziemi. Niektóre ekstremofile przeżywają w temperaturze powyżej $100^{\circ} \mathrm{C}$, inne w środowiskach silnie kwasowych i zasadowych, a jeszcze inne w warunkach bardzo wysokiego ciśnienia. ${ }^{44}$ Wiele ekstremofilów czerpie energię z egzotycznych reakcji chemicznych, włączając $\mathrm{w}$ to redukcję azotanów, redukcję siarki do siarkowodoru, utlenianie siarkowodoru do siarki, utlenianie żelaza żelazawego do żelaza żelazowego oraz redukcję $\mathrm{CO}_{2}$ do metanu (przez bakterie metanogeniczne). ${ }^{45}$ Bakteria Shewanella putrefaciens wykorzystuje atomy metalu (w tym wypadku manganu) w swoim metabolizmie w ten sam sposób, jak my wykorzystujemy atomy tlenu. Tak więc „oddycha” ona metalem. ${ }^{46}$ Thomas Gold twierdził (wzbudzając kontrowersje), że skały skorupy ziemskiej zawierają wielką masę ekstremofilów tworzących — jak to nazywa - „głęboką, gorącą biosferę", której całkowita biomasa jest równa biomasie całego znanego życia na powierzchni Ziemi. ${ }^{47}$

Pomimo niezwykłej różnorodności wszystkie ekstremofile wpisują się w taki sam podstawowy biologiczny projekt jak pozostałe życie ziemskie. Znaczy to, że ich polimery zbudowane są z kanonicznych sześciu atomów - węgla, azotu, wodoru, tlenu, siarki i fosforu - i wszystkie wymagają wody w stanie ciekłym, jak również wykorzystują DNA, RNA i białka.

W grudniu 2010 roku pojawiło się ekscytujące doniesienie, że niektóre ekstremofile mogą budować swoje polimery, wykorzystując pierwiastek alternatyw-

\footnotetext{
${ }^{44}$ Por. L.J. Rothschild and R.L. Mancinelli, „Life in Extreme Environments”, Nature 2001, vol. 409, s. 1092-1101, doi: 10.1038/35059215; Baross, Benner, Cody, Copley, Pace, Scott, and SHAPIRo, The Limits of Organic Life..., s. 32.

${ }^{45}$ Por. Rothschild and Mancinelli, „Life in Extreme Environments...”.

${ }^{46}$ Por. L.J. Rothschild, „Life in Extreme Environments: The Universe May Be More Habitable Than We Thought: Part 1", SpaceRef 18 June 2002, http://www.spaceref.com/news/viewne ws.html?id=463.

${ }^{47}$ Por. T. Gold, The Deep Hot Biosphere, Copernicus, New York 1998.
} 
ny wobec fosforu. Na konferencji prasowej pośpiesznie zorganizowanej przez NASA grupa badaczy kierowana przez Felisę Wolfe-Simon ${ }^{48}$ ogłosiła, że pewne ekstremofile zamieszkujące jezioro Mono (płytkie słone jezioro w Kalifornii) mogą zastępować fosfor w swoim DNA arsenem, o ile rosną w kulturach pozbawionych fosforu, a bogatych $\mathrm{w}$ arsen. Uznano, że rezultat ten ma „głębokie ewolucyjne i geochemiczne znaczenie". ${ }^{49} \mathrm{Z}$ pewnością, gdyby został potwierdzony, byłby to pierwszy przypadek użycia atomu spoza kanonicznej szóstki (węgla, tlenu, wodoru, azotu, siarki i fosforu) do budowy polimerów kluczowych dla życia. Jak się okazało, rezultatu tego nie potwierdzono, a interpretację danych eksperymentalnych należy uznać za błędną. ${ }^{50}$ Gdyby go potwierdzono, byłby to ważny wynik rozszerzający granice życia ziemskiego. Zważywszy jednak na to, że arsen jest bardzo podobny do fosforu, a podstawowy projekt życia pozostałby taki sam, to i tak nie stanowiłoby to zagrożenia dla ,węglowego szowinizmu", z perspektywy którego może powstać tylko życie oparte na węglu w wodnej macierzy.

Nic w obecnie znanym wszechświecie ekstremifilów nie zagraża kluczowemu argumentowi Hendersona, zgodnie z którym witalny zespót jest wyjątkowo dostosowany do tworzenia złożonych układów chemicznych związanych z życiem. Jednakże odkrycie tak wielu gatunków ekstremofilów w ciągu minionych kilkudziesięciu lat, często czerpiących energię z egzotycznych reakcji chemicznych, stwarza możliwość, że na Ziemi do odkrycia pozostało jeszcze więcej dziwnych i egzotycznych ekstremofilów. Niektóre mogą skrajnie odbiegać od kanonicznego, opartego na węglu projektu całego znanego, istniejącego życia. ${ }^{51}$ Kandydatami mogą być organizmy RNA (życie oparte na węglu, ale niewyko-

\footnotetext{
${ }^{48}$ Por. F. Wolfe-Simon, J.S. Blum, T.R. Kulp et al., „A Bacterium That Can Grow by Using Arsenic Instead of Phosphorus", Science 2010, vol. 332, s. 1163-1166, doi: 10.1126/science.1197 258.

${ }^{49}$ Wolfe-Simon, Blum, Kulp et al., „A Bacterium That Can Grow...”.

${ }^{50}$ Por. E.C. Hayden, „Study Challenges Existence of Arsenic-Based Life”, Nature online 20 January 2012, http://www.nature.com/news/study-challenges-existence-of-arsenic-based-life-1.98 61 (06.02.2013), doi: 10.1038/nature.2012.9861.

${ }^{51}$ Por. P.C.W. Davies, S.A. Benner, C.E. Cleland, C.H. Lineweaver, C.P. McKay, and F. Wolfe-Simon, „Signatures of a Shadow Biosphere”, Astrobiology 2009, vol. 9, s. 241-249, doi: 10.1089/ast.2008.0251.
} 
rzystujące DNA lub białek) będące reliktami świata RNA. ${ }^{52}$ Być może uda się odkryć nawet formy życia nieopartego na węglu, przypominające bazujące na glinie replikanty (rodzaj życia opartego na krzemie), o których mówił CairnsSmith. ${ }^{53}$

\section{Nowe świadectwa: astrobiologia}

Niektórzy badacze spekulowali na temat możliwości istnienia pozaziemskiego życia bazującego na innych związkach chemicznych niż węgiel. ${ }^{54}$ Część możliwych scenariuszy dyskutowano w ważnym badaniu NASA, zatytułowanym The Limits of Organic Life in Planetary Systems [Granice życia organicznego w układach planetarnych], ${ }^{55} \mathrm{w}$ którym udział wzięli najznamienitsi badacze w dziedzinie. Szczegółowo rozważono scenariusze życia bazującego na krzemie $\mathrm{w}$ ciekłym metanie lub $\mathrm{w}$ ciekłym azocie. ${ }^{56}$ Jako możliwe habitaty krzemowego życia $\mathrm{w}$ naszym układzie planetarnym ${ }^{57}$ podawano „węglowodorowe morza" na Tytanie ${ }^{58}$ lub hipotetyczny podpowierzchniowy ocean ciekłego

\footnotetext{
${ }^{52}$ Por. W. Gilbert, „Origin of Life: The RNA World”, Nature 1986, vol. 319, s. 618, doi: 10. 1038/319618a0.

${ }^{53}$ Por. A.G. CAirns-Smith, Genetic Takeover and the Mineral Origins of Life, Cambridge University Press, Cambridge, UK 1987.

${ }^{54}$ Por. Baross, Benner, Cody, Copley, Pace, Scott, and Shapiro, The Limits of Organic Life...; G. Feinberg and R. Shapiro, Life Beyond Earth: The Intelligent Earthling's Guide to Life in the Universe, Morrow, New York 1980; W. Bains, „Many Chemistries Could Be Used to Build Living Systems", Astrobiology 2004, vol. 4, s. 137-167, doi: 10.1089/153110704323175124; S.A. Benner, A. Ricardo, and M.A. Carrigan, „Is There a Common Chemical Model for Life in the Universe?", Current Opinion in Chemical Biology 2004, vol. 8, s. 672-689, doi: 10.1016/j.cbpa. 2004.10.003. fe....

${ }^{55}$ Por. Baross, Benner, Cody, Copley, Pace, Scott, and Shapiro, The Limits of Organic Li-

${ }^{56}$ Por. Benner, Ricardo, and Carrigan, „Is There a Common Chemical Model...”. s. 160.

${ }^{57}$ Por. Irwin and Schulze-Makuch, Cosmic Biology..., s. 264; Bains, „Many Chemistries...”,

${ }^{58}$ Por. Benner, Ricardo, and Carrigan, „Is There a Common Chemical Model...”, s. 679.
} 
azotu na Trytonie. ${ }^{59}$ Co ciekawe, o możliwości życia opartego na krzemie krótko wspomniał również Henderson. ${ }^{60}$

Ocena prawdopodobieństwa możliwości istnienia obcego życia jest, rzecz jasna, problematyczna. Być może prawa przyrody dopuszczają istnienie ,pływaków" - ogromnych gazowych istot, które zgodnie z hipotezą Carla Sagana mogą zamieszkiwać atmosferę Jowisza ${ }^{61}$ - lub elektronicznych form życia we wnętrzach gwiazd, takich jak „plazmoby”, o których pisali Feinberg i Shapiro w książce Life Beyond Earth [Życie poza Ziemią]. ${ }^{62}$ Dopóki jednak nie przedstawimy względnie szczegółowych opisów takich obcych istot, łącznie z wyjaśnieniem, jak one powstały, jak się rozwijają i reprodukują, jakie mają „narządy zmysłowe”, jak one „myślą" i tak dalej, bardzo trudno będzie je traktować jako poważne wyzwanie dla ,węglowego szowinizmu”.

Nawet w przypadku być może najwiarygodniejszego scenariusza - możliwości istnienia w niskich temperaturach obcego życia opartego na krzemie ${ }^{63}$ wskazywano jedynie na część podstawowych chemicznych cegiełek budulcowych (monomerów obcych form życia). Rozważano też tylko pewne możliwe źródła energii potrzebnej do przeprowadzania syntez i możliwy sposób tworzenia złożonych cząsteczek z monomerów. Wyższa organizacja hipotetycznych krzemowych form życia, wliczając w to analogi błon komórkowych, enzymów, systemów kodujących i tak dalej, nigdy nie była dyskutowana. Jak wskazują badacze NASA odnośnie do krzemowych makrocząsteczek: „Mamy pewne pomysły na temat tego, jak mogły one spontanicznie powstać, by utrzymać biosferę". ${ }^{64}$ Rothschild, czołowa badaczka w dziedzinie ekstremofilów, wyznała, że

\footnotetext{
${ }^{59}$ Por. BAINs, „Many Chemistries...”, s. 146.

${ }^{60}$ Por. Henderson, The Fitness of the Environment..., s. 66.

${ }^{61}$ Por. C. SAGan, Kosmos, przeł. Maria Duch i Bronisław Rudak, Wydawnictwo Zysk i S-ka, Poznań 1997, s. 48.

${ }^{62}$ Por. Feinberg and Shapiro, Life Beyond Earth..., s. 382.

${ }^{63}$ Por. Baross, Benner, Cody, Copley, Pace, Scott, and Shapiro, The Limits of Organic Life...; Bains, „Many Chemistries...”; Benner, Ricardo, and CARrigan, „Is There a Common Chemical Model...".

${ }^{64}$ Baross, Benner, Cody, Copley, Pace, Scott, and Shapiro, The Limits of Organic Life..., s. 2,6 .
} 
„Mimo że krzem także występuje powszechnie (choć nawet nie w przybliżeniu tak powszechnie jak węgiel w całym Wszechświecie) i może tworzyć interesujące polimery [...] jego elastyczność blednie w porównaniu z chemią organiczną, zwłaszcza jeśli chodzi o zdolność węgla do tworzenia polimerów". ${ }^{65}$ Poglądy te znalazły oddźwięk u Pace'a, który podkreślał wyjątkowe dostosowanie węgla do życia, czego nie można powiedzieć o krzemie. ${ }^{66}$

Co więcej, jak komentują Irwin i Schultze-Makuch:

Świat, w którym krzem stanowiłby lepszą podstawę dla życia niż węgiel, byłby albo skrajnie zimny, nie zawierałby tlenu i występowałaby w nim stabilna ciecz inna niż woda (dla silanów), albo tak gorący, że jedyną cieczą byłby zapewne stopiony minerał (krzemiany). W obu przypadkach skomplikowane reakcje chemiczne porównywalne do metabolizmu węglowego byłyby znacznie mniej prawdopodobne z powodu ekstremalnych temperatur [...] Wreszcie, dane empiryczne przemawiają przeciwko życiu bazującemu na krzemie [...] [Chociaż krzem] występuje powszechniej niż węgiel na większości skalistych planet łącznie z naszą, to nie znaleziono żadnych form życia opartego wyłącznie na krzemie, podczas gdy w meteorytach, które przybyły na Ziemię z przestrzeni kosmicznej, znaleziono wiele złożonych związków organicznych, w tym aminokwasy (cegiełki budulcowe białek). ${ }^{67}$

Plaxco i Gross również mają sceptyczny stosunek do krzemu:

Krzem jest w mniejszym stopniu dostosowany do tworzenia złożonej chemii i dlatego powstanie życia bazującego na krzemie wydaje się znacznie mniej prawdopodobne niż życia opartego na węglu. Jeśli więc kiedykolwiek odwiedzą nas kosmici, to najpewniej powinniśmy powitać ich tortami zrobionymi ze związków węglowych, a nie z krzemowych skał. Węgiel wygrywa z krzemem [...] a inne pierwiastki występujące w przyrodzie $[. .$.$] są w jeszcze gorszej sytuacji! { }^{68}$

Podsumowując, jeśli wykluczymy krzem, może to oznaczać, że tylko atom węgla może stanowić podstawę budowy układów ożywionych.

${ }^{65}$ L.J. RothschiLd, „The Evolution of Photosynthesis... Again?”, Philosophical Transactions of the Royal Society B: Biological Sciences 2008, vol. 363, s. 2792 [2787-2801], doi: 10.1098/rs tb.2008.0056.

\footnotetext{
${ }^{66}$ Por. PACE, ,Special Feature...”.

${ }^{67}$ Irwin and Schulze-Makuch, Cosmic Biology..., s. 29.

${ }^{68}$ Plaxco and Gross, Astrobiology..., s. 13.
} 


\section{Problem emergencji}

Ocenę wyżej wspomnianych scenariuszy poważnie utrudnia występowanie zjawiska emergencji. Niemal wszystkie rodzaje cząsteczek, nawet te najprostsze, jak woda, mają właściwości, których nie da się przewidzieć nawet mimo najbardziej wyczerpującego zbadania właściwości ich składników. ${ }^{69}$ Emergencja to szczególnie trudny problem na poziomie mezoskopowej materii, ${ }^{70} \mathrm{~W}$ kontekście którego należy dokonywać oceny możliwości zachodzenia egzotycznych reakcji biochemicznych i powstawania egzotycznych supramolekularnych struktur. W rezultacie możliwość istnienia obcych form życia można potwierdzić tyl-

\footnotetext{
${ }^{69}$ Por. J.R. Platt, „Properties of Large Molecules That Go Beyond the Properties of Their Chemical Subgroups", Journal of Theoretical Biology 1961, vol. 1, s. 342-358; R.B. Laughuin, D. Pines, J. Schmalian, B.P. Storkovic, and P. Wolynes, „The Middle Way”, Proceedings of the National Academy of Sciences USA 2000, vol. 97, s. 32-37, doi: 10.1073/pnas.97.1.32.

Dobrym przykładem problemu emergencji w tej dziedzinie jest dobitny fakt, że pomimo ogromnego wzrostu wiedzy o chemicznych i fizycznych właściwościach cząsteczek RNA oraz ogromnego wysiłku poświęconego przeszukiwaniu przestrzeni sekwencyjnej RNA w celu znalezienia funkcjonalnych rybozymów nikt nie wie, czy istnieje samopowielający się rybozym. $\mathrm{Z}$ pewnością nikt nie jest $\mathrm{w}$ stanie zaprojektować takiego rybozymu na podstawie założeń teoretycznych. Pierwszą próbę znalezienia go podjęto w 2001 roku i zidentyfikowano rybozym, który potrafi kopiować krótką sekwencję RNA (18 nukleotydów), ale nie kopiuje samego siebie (189 nukleotydów) (por. W.K. Johnston, ,RNA-Catalyzed RNA Polymerization: Accurate and General RNA-Templated Primer Extension”, Science 2001, vol. 292, s. 1319-1325, doi: 10.1126/science. 1060786). Drugą próbę podjęto w 2009 roku, kiedy zespół Joyce’a ogłosił odkrycie krzyżowo powielającej się pary rybozymów (enzymów RNA), każdy o długości około 70 nukleotydów, które mogą wzajemnie katalizować swoją syntezę (por. T.A. Lincoln and G.F. Joyce, „Self-Sustained Replication of an RNA Enzyme", Science 2009, vol. 323, s. 1229-1232, doi: 10.1126/science.116 7856). W zeszłym roku zespół Holligera zidentyfikował rybozym zdolny do kopiowania sekwencji o długości 95 nukleotydów, czyli prawie połowy swojej długości (por. A. Wochner, J. AтtwATer, A. Coulson, and P. Holliger, „Ribozymecatalyzed Transcription of an Active Ribozyme”, Science 2011, vol. 332, s. 209-212, doi: 10.1126/science.1200752). Dalej jednak daleko nam do otrzymania samopowielającego się rybozymu wymaganego w ramach hipotezy świata RNA, to jest do otrzymania cząsteczki mogącej kopiować samą siebie i dowolny inny rybozym. To przedsięwzięcie, będące nadal w toku, służy jako klasyczne przypomnienie, że złożone makrocząsteczki mają właściwości emergentne. $Z$ dokładnie tym samym zjawiskiem emergencji musi się zmierzyć każda próba urzeczywistnienia dowolnego typu obcego życia, nawet te próby, którym towarzyszą względnie szczegółowe scenariusze.

${ }^{70}$ Por. Laughlin, Pines, Schmalian, Stojkovic, and Wolynes, „The Middle Way...”; R.B. LauGHLIN and D. PInes, „The Theory of Everything”, Proceedings of the National Academy of Sciences USA 2000, vol. 97, s. 28-31, doi: 10.1073/pnas.97.1.28.
} 
ko na drodze empirycznej w badaniach laboratoryjnych, podejmując próby syntezowania przynajmniej niektórych podstawowych ich składników i jakichś bardziej złożonych supramolekularnych struktur. Jednak nikt takich prób nie podjął. Nie zbliżamy się w żaden sposób do stworzenia krzemowych form życia w laboratorium lub form życia opartego na węglu zdolnych do życia w ciekłym amoniaku. Po prostu nie potrafimy rozstrzygnąć, czy życie bazujące na alternatywnych chemiach jest realne.

W istocie nie wiemy, czy najlepszy kandydat na alternatywną formę życia — organizmy RNA — mógłby naprawdę istnieć. ${ }^{71}$ Nawet jeśli dopuścimy możliwość świata RNA na wczesnej Ziemi, lub jego współczesne istnienie w jakiejś niezbadanej niszy, to i tak organizmy RNA będą wodnymi formami życia opartego na węglu, które wykorzystują większość elementów zespołu Hendersona. Jak wynika z przeglądu literatury, żaden z bardziej „odległych” astrobiologicznych scenariuszy nie stanowi wyzwania dla ujęcia Hendersona. Chris McKay, jeden $\mathrm{z}$ ojców astrobiologii, przyznaje, że duża część rozważań w dziedzinie astrobiologii jest wysoce spekulatywna. W niedawnym wywiadzie wyjawił, że „Ostatnio wielu ludzi — zachęconych nową modą na astrobiologię — lubi głosić coś, co można nazwać niedzielnymi teoriami. Życie mogłoby bazować na przykład na borze i o czymś takim się pisze. Ale to jedynie spekulacje. ${ }^{72}$

\section{Podsumowanie}

Żadne dane z zakresu egzobiologii czy biologii ekstremofilów nie zagrażają tezie Hendersona o wyjątkowym i wyłącznym dostosowaniu witalnego zespotu do tworzenia złożonych układów chemicznych. Nic także nie przeczy jego tezie, że Wszechświat jest „w swojej istocie biocentryczny”. Teza ta nie implikuje jednak, że dostosowanie witalnego zespolu jest tak sztywne, że z prawami przyrody zgodny jest tylko bardzo szczególny rodzaj życia opartego na węglu, który istnieje obecnie na Ziemi (cukry D, kanoniczne L-aminokwasy, DNA, RNA i białka). Życie może obejmować na przykład organizmy zbudowane z białek korzy-

\footnotetext{
${ }^{71}$ Por. przyp. 69.

${ }^{72}$ Por. S. MAzur, The Altenberg 16: An Exposé of the Evolution Industry, North Atlantic Books, Berkeley, California 2010, s. 210.
} 
stających z innych aminokwasów lub innych polimerów genetycznych, ${ }^{73}$ być może włącznie z niedawno ogłoszonym kseno DNA ${ }^{74}$ lub nawet hipotetycznymi organizmami RNA.

To jednak zdumiewające, że pomimo różnorodności ekstremofilów wszystkie one stanowią przykłady życia opartego na węglu w wodnej macierzy. A jeszcze bardziej zdumiewa to, że żadne z nich nie odbiegają (zwłaszcza gdy dowiedziono, że ekstremofile żywiące się arsenem nie istnieją) od kanonicznego, znanego biochemicznego projektu składającego się z sześciu kanonicznych atomów, białek utworzonych z dwudziestu znanych aminokwasów, DNA i RNA zbudowanych z kanonicznych nukleotydów, mają też taki sam kod genetyczny, dzielą wiele takich samych szlaków metabolicznych i otoczone są taką samą dwuwarstwową błoną lipidową!

Dopóki nie zostaną odkryte formy życia wyraźnie odbiegające od standardowego życia ziemskiego lub dopóki nowe formy życia znacznie odmienne od istniejącego życia nie zostaną stworzone w laboratorium, teza, że prawa przyrody są dostosowane do skrajnie innych, ,nieziemskich” typów życia, nie będzie miało empirycznej podstawy. Mimo że nadal podnoszone są głosy krytyczne, ${ }^{75}$ większość badaczy przyznaje, że podstawowy argument Hendersona przetrwał sprawdzian stu lat rozwoju wiedzy naukowej. Teza Hendersona, zgodnie z którą podstawowe biochemiczne składniki życia tworzą wyjątkowy, synergiczny zespót chemicznego dostosowania do życia, ${ }^{76}$ nigdy nie została unieważniona ani poprzez odkrycie jakiejś alternatywnej biochemii, ani za sprawą jakiegoś dobrze opracowanego alternatywnego scenariusza. Co więcej, wielu badaczy, prawdopodobnie nawet większość, nadal broni poglądu o wyjątkowym dostosowaniu węgla i wody do życia. Nawet Carl Sagan przyznawał, że w duchu był szowini-

\footnotetext{
${ }^{73}$ Por. Baross, Benner, Cody, Copley, Pace, Scott, and Shapiro, The Limits of Organic Life..., rozdz. 4; S. Greiss and J.W. Chin, „Expanding the Genetic Code of an Animal”, Journal of the American Chemical Society 2011, vol. 133, s. 14196-14199, doi: 10.1021/ja2054034.

${ }^{74}$ Por. V.B. Pinheiro, A.I. Taylor, C. Cozens et al., „Synthetic Genetic Polymers Capable of Heredity and Evolution”, Science 2012, vol. 336, s. 341-344, doi: 10.1126/science.1217622.

${ }^{75}$ Por. Bains, „Many Chemistries...”; Benner, Ricardo, and Carrigan, „Is There a Common Chemical Model...”; V.J. STEnger, Timeless Reality: Symmetry, Simplicity, and Multiple Universes, Prometheus Books, Amherst, New York 2000.

${ }^{76}$ Por. Henderson, The Fitness of the Environment....
} 
stą węgla i wody. ${ }^{77}$ Jak na ironię, mimo że badacze NASA spekulują na temat możliwości alternatywnych biologii, spekulacje te pozostają tak niejasne, że projektując realne programy wykrywania życia w kosmosie, zawsze szukają oznak życia opartego na węglu, na przykład śladów atmosfery zawierającej tlen. ${ }^{78}$ To kolejne milczące przyznanie, że przyroda jest wyjątkowo dostosowana do życia ziemskiego.

\section{Dostosowanie przyrody do fizjologii czlowieka}

W The Fitness Henderson wychwala biocentryczność przyrody, ale nie twierdzi otwarcie, że właściwości podstawowych substancji biochemicznych witalny zespót - cechują się wyjątkowym dostosowaniem do zaawansowanych istot opartych na węglu, takich jak my, wliczając $w$ to nasz fizjologiczny projekt. Byłaby to znacznie mocniejsza i konkretniejsza teza antropocentryczna. Mimo to w The Fitness Henderson, omawiając właściwości poszczególnych substancji chemicznych, często zwraca uwagę na ich szczególne dostosowanie do biologii czlowieka. ${ }^{79}$ Gdy pisze on o ,wspaniałych korzyściach, jakie ocean niesie dla wspólnoty istot żywych", ${ }^{80}$ lub gdy twierdzi, że środowisko naszej planety jest „maksymalnie przyjaznym domem dla organizmów żywych”, ${ }^{81}$ wyraźnie ma na myśli dostosowanie nie tylko do prostych form życia bazującego na węglu, to jest życia opartego na węglu w ogóle, lecz również dostosowanie do organizmów wyższych, w tym takich istot jak my.

W rzeczy samej, dostosowanie właściwości witalnego zespołu do możliwości istnienia „Zwierzęcia, takiego jak człowiek”, ${ }^{82}$ staje się oczywiste, jeśli rozważy się właściwości niektórych podstawowych substancji biochemicznych zespołu. Część właściwości zespołu jest korzystna dla fizjologii człowieka, ale jest

\footnotetext{
${ }^{77}$ Por. SAGan, Kosmos..., s. 125.

${ }^{78}$ Por. Catling, Glein, Zahnle, and McKay, „Why $\mathrm{O}_{2}$ Is Required...”.

${ }^{79}$ Por. Henderson, The Fitness of the Environment..., s. 89, 102, 139.

${ }^{80}$ Henderson, The Fitness of the Environment..., s. 190.

${ }^{81}$ Henderson, The Fitness of the Environment..., s. 53.

${ }^{82}$ Henderson, The Fitness of the Environment..., s. 102.
} 
nieistotna lub wręcz niekorzystna dla innych form życia opartego na węglu. Chociaż liczne świadectwa dostosowania do życia bazującego na węglu jako takiego były dostępne już w 1913 roku, to wiele świadectw dotyczących fizjologii ssaków (przeglądu tych świadectw dokonam w dalszej części artykułu) odkryto dopiero po Hendersonie. Potwierdzają one pogląd, że przyroda jest szczególnie dostosowana do organizmów przypominających nas.

\section{Woda}

Dostosowanie termicznych właściwości wody do życia po raz pierwszy omówił Whewell $\mathrm{w}$ swoim Bridgewater Treatise [Traktacie z Bridgewater], ${ }^{83}$ a później wspomniał o nim Wallace. ${ }^{84} \mathrm{~W}$ The Fitness Henderson wykazał, że wysoka wydajność termiczna wody wspomaga utrzymywanie stałej temperatury ciała u organizmów stałocieplnych, ${ }^{85}$ natomiast wysoki stopień jej chłodzenia poprzez parowanie $\mathrm{w}$ wielkiej mierze wspomaga lądowe organizmy stałocieplne w oddawaniu ciepła, gdy temperatura otoczenia jest bliska $38^{\circ} \mathrm{C}$. Jak sam to ują:

U zwierzęcia, takiego jak człowiek, którego metabolizm jest bardzo intensywny, ciepło stanowi główny produkt wydalania wymagający nieustannej eliminacji w dużych ilościach. Dostępne są tylko trzy środki do tego celu: przewodnictwo, promieniowanie i parowanie wody [...] W niskiej temperaturze woda paruje w niewielkim stopniu, zaś w temperaturze ciała lub wyższej ciepło nie może być oddawane poprzez przewodnictwo i promieniowanie, a więc całą tę pracę wykonuje parowanie. ${ }^{86}$

Co dziwne, Henderson nie wspomniał o tym, że te dwie właściwości są nieistotne dla olbrzymiej większości form ziemskiego życia opartego na węglu. Bardzo oczywistym przykładem jest zupełna nieistotność wysokiej wydajności cieplnej lub wysokiego stopnia chłodzenia wody poprzez parowanie dla ekstre-

\footnotetext{
${ }^{83}$ Por. W. Whewel, Astronomy and General Physics Considered with Reference to Natural Theology, 1st ed., Bridgewater Treatise, vol. 3, Pickering, London 1833.

${ }^{84}$ Por. Flannery, Dembski, and Wallace, Alfred Russel Wallace's Theory of Intelligent Evolution..., rozdz. 7.

${ }^{85}$ Por. Henderson, The Fitness of the Environment..., s. 89.

${ }^{86}$ Henderson, The Fitness of the Environment..., s. 102 [wyróżnienie dodane].
} 
mofilów żyjących w pobliżu ciemnych dymników w głębinach oceanicznych lub dla mieszkańców głębokiej, gorącej biosfery, o której pisał Gold. ${ }^{87}$ Kolejnym przykładem mogą być ekstremofile żyjące w niskich temperaturach, które mogą rozwijać się przy $-15^{\circ} \mathrm{C}$, być może w marsjańskich piaskach. ${ }^{88}$ Tę ostatnią możliwość sprawdza obecnie marsjański łazik Curiosity. Wreszcie, większość organizmów wodnych czerpie niewiele albo żadnych bezpośrednich korzyści adaptacyjnych z wysokiego utajonego ciepła parowania wody. ${ }^{89}$

Wysoka wydajność termiczna wody stanowi wyzwanie także dla organizmów egzotermicznych próbujących ogrzać się w zimne poranki. Małe lądowe organizmy, jak trzmiele i ważki, muszą dygotać swoim ciałem przed lotem, aby podnieść temperaturę swoich mięśni. Nawet duże zmiennocieplne organizmy, jak jaszczurki i węże, mogą być odrętwiałe w zimne poranki i muszą wygrzewać się w promieniach słońca. Niektóre mają specjalne adaptacje, na przykład krokodyle mają łuski wypełnione krwią, które działają jak panele słoneczne. ${ }^{90}$ Permski gad ssakokształtny Dimetrodon używał wielkiego żagla na grzbiecie jako pochłaniacza ciepła, by podnieść temperaturę ciała. Żagiel mógł być skierowany ku słońcu, aby przyspieszyć ogrzewanie, co mogło umożliwiać Dimetrodonowi polowanie, zanim ofiara stała się aktywna. Bramwell i Fellgett ${ }^{91}$ obliczyli, że gdyby ważący $250 \mathrm{~kg}$ (440 funtów) Dimetrodon nie miał żagla, podniesienie temperatury jego ciała z $26^{\circ} \mathrm{C}$ do $32^{\circ} \mathrm{C}\left(\mathrm{z} 79^{\circ} \mathrm{F}\right.$ do $\left.90^{\circ} \mathrm{F}\right)$ zajęłoby trzy i pół godziny.

\footnotetext{
${ }^{87}$ Por. Gold, The Deep Hot Biosphere....

${ }^{88}$ Por. Baross, Benner, Cody, Copley, Pace, Scott, and Shapiro, The Limits of Organic Life..., s. 32 .

${ }^{89}$ Wysoki stopień chłodzenia wody poprzez parowanie odgrywa ważną rolę w utrzymywaniu stabilnej temperatury hydrosfery, co niesie pośrednią korzyść dla całego życia na Ziemi. Henderson omawia znaczenie tej właściwości wody w The Fitness (por. Henderson, The Fitness of the Environment..., s. 92-102). Zaktualizowane omówienie wkładu tej właściwości do stabilizacji globalnej temperatury znajduje się w książce Toma Garrisona, Oceanography (por. GarRison, Oceanography..., rozdz. 6).

${ }^{90}$ Por. M.R. SeIDEL, „The Osteoderms of the American Alligator and Their Functional Significance", Herpetologica 1979, vol. 35, s. 375-380.

${ }^{91}$ Por. C.D. Bramwell and P.B. Fellgett, „Thermal Regulation in Sail Lizards”, Nature 1973, vol. 242, s. 203-205, doi: 10.1038/242203a0.
} 
Szczególnie fascynującym aspektem wysokiego utajonego ciepła parowania wody jest to, że może być to jedyny element dostosowania środowiska, który jest zapewne korzystniejszy dla współczesnych ludzi niż dla innych stałocieplnych zwierząt lądowych. Jako istoty pozbawione sierści ludzie oddają ciepło poprzez parowanie wydajniej od pozostałych ssaków. W rezultacie w gorącu południowego afrykańskiego słońca ludzie mogą biec bez ustanku dłużej niż jakiekolwiek inne zwierzę. Ta zdolność mogła stanowić dla człowieka ogromną pomoc w polowaniach na plejstoceńskiej sawannie. ${ }^{92}$

Kolejną właściwością wody, która nie została omówiona w The Fitness, a która jest szczególnie dostosowana do dużych, metabolicznie aktywnych organizmów, jest jej niska lepkość. Umożliwia to przepływ krwi przez naczynia włosowate, a także ułatwia szybką dyfuzję potrzebnych składników pokarmowych oraz odpadów metabolicznych do tkanek i z tkanek do krwiobiegu. ${ }^{93}$ Ponieważ niska lepkość wody umożliwia przepływ krwi przez bardzo wąskie kanały o średnicy zaledwie trzech lub czterech mikronów, objętość naczyń włosowatych stanowi tylko względnie mały ułamek masy tkanek. Gdyby lepkość wody była nieco większa, to układ krążenia, jaki występuje obecnie u organizmów wyższych, a nawet jakikolwiek układ krążenia, nie mógłby powstać.

Złożony układ sercowo-naczyniowy, którego zadaniem jest dyfuzja składników pokarmowych, eliminacja odpadów oraz wymiana gazów, jest zasadniczym aspektem projektu wszystkich zaawansowanych, metabolicznie aktywnych organizmów. Natomiast proste, jednokomórkowe formy życia opartego na węglu potrafią pozyskiwać składniki pokarmowe zaspokajające ich metaboliczne potrzeby poprzez dyfuzję bezpośrednio ze środowiska, dzięki czemu nie potrzebują pomocniczych układów fizjologicznych. Co więcej, wątpliwe jest, czy gdyby lepkość wody była dwukrotnie lub trzykrotnie większa niż teraz, wywarłoby to

\footnotetext{
${ }^{92}$ Por. D.E. Lieberman, D.M. Bramble, D.A. Raichlen, and J.J. Shea, „Brains, Brawn, and the Evolution of Human Endurance Running Capabilities", w: F.E. Grine, J.G. Fleagle, and R.E. Leakey (eds.), Stony Brook Human Evolution Symposium and Workshop: The First Humans — Origin and Early Evolution of the Genus Homo, Springer, Dordrecht 2009, s. 77-92.

${ }^{93}$ Tempo dyfuzji jest dostatecznie wysokie, by małe cząsteczki mogły przebyć średni dystans w komórce ciała w ułamku sekundy (por. G. KARP, Cell and Molecular Biology: Concepts and Experiments, 6th ed., John Wiley and Sons Inc., New Jersey 2009, s. 18; Denton, Nature's Destiny..., s. 32-34).
} 
negatywny wpływ na wiele organizmów jednokomórkowych. Gdy temperatura zwiększa się od $20^{\circ} \mathrm{C}$ do $100^{\circ} \mathrm{C}$, lepkość wody zmniejsza się prawie czterokrotnie, ${ }^{94}$ a więc na przykład ekstremofile żyjące $\mathrm{w}$ wysokich temperaturach i tak przeprowadzałyby bardzo szybką dyfuzję metabolitów, nawet gdyby lepkość wody była dwukrotnie większa. Niektóre organizmy, jak pleśń, potrafią dobrze prosperować $\mathrm{w}$ temperaturze otoczenia w bardzo lepkich i gęstych roztworach cukru. ${ }^{95}$ Wygląda na to, że wiele rodzajów jednokomórkowego życia mogłoby świetnie się rozwijać, nawet gdyby lepkość wody była kilkakrotnie większa, ale nie byłoby tak w przypadku złożonych organizmów wielokomórkowych, takich jak my.

\section{Tlen}

Kolejnym składnikiem witalnego zespołu Hendersona, mającym właściwości szczególnie dostosowane do dużych, oddychających powietrzem, homeotermicznych (stałocieplnych) organizmów, jak ludzie, jest tlen. ${ }^{96}$ Wiele aspektów jego dostosowania do naszej biologii wyraźnie odkryto dopiero po Hendersonie.

Generowanie energii u ludzi i wszystkich złożonych wielokomórkowych zwierząt zachodzi w sposób następujący:

$$
\underset{\text { tlen }}{\text { zredukowane związi węgla }+}=\quad \begin{gathered}
\text { woda } \\
\text { energia chemiczna }
\end{gathered}
$$

Ten wzór może wydawać się zbyt dobrze znany, by wymagał komentarza. Jest to jednak przykład tego, że znajomość zjawiska utrudnia docenienie jego niezwykłości. Ta kluczowa, życiodajna reakcja jest możliwa wyłącznie u takich istot jak my, ponieważ fizyczne i chemiczne właściwości substratów i produktów końcowych — tlenu, wody, $\mathrm{CO}_{2}$ — są niemal dokładnie takie, jakie są!

\footnotetext{
${ }^{94}$ Por. J. Kestin, M. Sokolov, and W.A. Wakeham, „Viscosity of Liquid Water in the Range $-8^{\circ} \mathrm{C}$ to $150^{\circ} \mathrm{C}$ ", Journal of Physical and Chemical Reference Data 1978, vol. 7, s. 941-948. s. 32 .

${ }^{95}$ Baross, Benner, Cody, Copley, Pace, Scott, and Shapiro, The Limits of Organic Life...,

${ }^{96}$ Por. Henderson, The Fitness of the Environment..., s. 272.
} 
Utlenianie dostarcza znacznie więcej energii niż olbrzymia większość innych reakcji chemicznych i powszechnie uznaje się, że tylko utlenianie daje dostateczną ilość energii do utrzymywania metabolicznie aktywnych organizmów. ${ }^{97}$ Dotyczy to każdego złożonego życia opartego na węglu. Dlatego, jak wspomniano wyżej, identyfikacja tlenu w atmosferach planet pozasłonecznych traktowana jest jako możliwa oznaka zaawansowanego życia bazującego na węglu. ${ }^{98}$

Trudno wyobrazić sobie, jak inaczej energia czerpana z utleniania mogłaby być wykorzystywana przez istoty lądowe, jeśli nie do oddychania tlenem jako gazem z atmosfery. (Nigdy nie zaproponowano poważnych scenariuszy wykorzystywania przez organizmy lądowe tlenu w postaci ciekłej lub stałej.) Fakt, że tlen jest gazem w temperaturze otoczenia, niesie więc ewidentną korzyść, gdyż umożliwia oddychanie powietrzem takim organizmom jak my.

Bardzo aktywne organizmy, jak my, potrzebują tlenu w dużych ilościach. Co zaskakujące, dorosły człowiek zużywa około $250 \mathrm{ml}$ tlenu na minutę w spoczynku i $5000 \mathrm{ml}$ na minutę w trakcie intensywnych ćwiczeń. ${ }^{99}$ Tak wysokie tempo zużywania tlenu jest możliwe tylko dzięki bezpośredniemu pobieraniu tlenu z bogatej w tlen atmosfery, w stężeniach dostatecznie dużych, by umożliwiało to szybką i wydajną absorpcję w naszych płucach. (Powody, dla których alternatywy nie może stanowić absorpcja tlenu rozpuszczonego w wodzie, to jest za pośrednictwem skrzeli, zostaną przedstawione w dalszej części artykułu.)

Nasza obecna atmosfera zawiera $21 \%$ tlenu i wytwarza ciśnienie cząstkowe około $150 \mathrm{~mm} \mathrm{Hg}$. Ten poziom tlenu jest potrzebny, aby utrzymywać aktywny metabolizm, na co wskazuje zmęczenie towarzyszące wspinaczce na dużych wysokościach, gdzie ciśnienie cząstkowe jest znacznie mniejsze niż $150 \mathrm{~mm}$ Hg. Z drugiej strony, gdyby poziom tlenu w atmosferze wzrósł znacznie powy-

\footnotetext{
${ }^{97}$ Por. T. Fenchel and B.J. Finlay, Ecology and Evolution in Anoxic Worlds, Oxford University Press, Oxford 1995.

${ }^{98}$ Por. Catling, Glein, Zahnle, and McKay, „Why O $\mathrm{O}_{2}$ Is Required...”.

${ }^{99}$ Por. J.N. MaINA, „Comparative Respiratory Morphology: Themes and Principles in the Design and Construction of the Gas Exchangers", The Anatomical Record (New Anat.) 2000, vol. 261 , s. $26[25-44]$.
} 
żej $21 \%$, groziłoby to spontanicznym spalaniem związków węgla. ${ }^{100}$ Fakt, że poziomy tlenu wystarczające do utrzymywania wysokiego tempa metabolizmu przez organizmy oddychające powietrzem jednocześnie nie umożliwiają spontanicznego spalania się, to ewidentny zbieg okoliczności o ogromnym znaczeniu dla życia ziemskiego.

W istocie poziom tlenu może osiągać tylko $21 \%$, ponieważ tlen jest względnie obojętny $\mathrm{w}$ temperaturach poniżej $50^{\circ} \mathrm{C}$, co jest skutkiem jego osobliwej struktury atomowej, która osłabia swoją reaktywność w temperaturze otoczenia. ${ }^{101}$ Wysokie tempo metaboliczne u ssaków nie mogłoby być utrzymywane, gdyby nie to osłabienie. Jak komentuje Boulatov, „Ta obojętność $\mathrm{O}_{2}$ jest bardzo korzystna dla biosfery, gdyż umożliwia istnienie mocno zredukowanej materii organicznej w atmosferze bogatej w silny utleniacz". ${ }^{102}$ Jak na ironię, ta obojętność chemiczna jest tak wyraźna, że stwarza problem fizjologiczny. Boulatov kontynuuje: „Taka obojętność oznacza również, że szybkie utlenianie tlenowe nastąpi tylko, jeśli do układu dostarczona zostanie energia umożliwiająca przełamanie wewnętrznych barier kinetycznych, czyli jeśli reakcja ulegnie katalizie". ${ }^{103}$ Zespół Prokofievej, dyskutując obojętność tlenu, także zauważa konieczność katalizy w celu aktywacji atomu tlenu w temperaturze otoczenia:

Tlen cząsteczkowy to najprzyjaźniejszy dla środowiska i najtańszy reagent do utleniania organicznych substratów. Jednakże, z powodu swojej obojętności kinetycznej, tlen cząsteczkowy musi być aktywowany, zanim będzie mógł być zastosowany w reakcji utleniania. Aby móc spełniać to zadanie w łagodnych warunkach, przyroda wykształciła wymyślne enzymy, które w swoich aktywnych miejscach zawierają jony żelaza lub miedzi. ${ }^{104}$

\footnotetext{
${ }^{100}$ Por. Lovelock, Gaja..., s. 53.

${ }^{101}$ Por. M.J. Green and A.O. Hill, „The Chemistry of Dioxygen”, Methods in Enzymology 1984, vol. 105, s. 3-22.

${ }^{102}$ R. Boulatov, „Understanding the Reaction that Powers this World: Biomimetic Studies of Respiratory $\mathrm{O}_{2}$ Reduction by Cytochrome Oxidase", Pure and Applied Chemistry 2004, vol. 76, s. 304 [303-319], doi: 10.1351/pac200476020303.

${ }^{103}$ Boulatov, „Understanding the Reaction...”, s. 304.

${ }^{104}$ A. Prokofieva, A.I. Prikhod'ko, S. Dechert, and F. Meyer, „Selective Benzylic C-C Coupling Catalyzed by a Bioinspired Dicopper Complex”, Chemical Communications 2008, vol. 8, s. 1005 [1005-1007], doi: 10.1039/b718162k.
} 
Na szczęście takie metale przejściowe jak żelazo i miedź mają dokładnie takie cechy atomowe, które umożliwiają aktywację atomu tlenu w reakcji chemicznej. ${ }^{105} \mathrm{~A}$ więc obojętność tlenu $\mathrm{w}$ temperaturze otoczenia ratowana jest przez wyjątkowe właściwości metali przejściowych, przywracające jego użyteczność do generowania energii u aktywnych organizmów oddychających powietrzem, u których wysokie tempo metabolizmu oraz ,aktywny tryb życia” są całkowicie zależne od energii utleniania.

\section{Dostosowanie tlenu do organizmów oddychających powietrzem}

Obojętność tlenu we względnie dużych stężeniach i w temperaturze otoczenia jest, podobnie jak chłodzenie wody poprzez parowanie, szczególnie dostosowana do organizmów oddychających powietrzem, które pobierają tlen w postaci gazowej. To dostosowanie nie ma jednak zastosowania do organizmów oddychających w wodzie. Rozpuszczalność tlenu w wodzie jest względnie niska, a to, łącznie $\mathrm{z}$ większą lepkością wody w porównaniu z powietrzem, w wielkim stopniu ogranicza tempo, w jakim tlen może być ekstrahowany z wody. Jak komentuje Maina:

Powietrze, jako ośrodek oddychania, jest bardziej opłacalne: woda jest 50 razy bardziej lepka niż powietrze. Stężenie tlenu rozpuszczonego w wodzie wynosi około jednej trzydziestej stężenia tlenu w powietrzu. Tempo dyfuzji tlenu w wodzie jest mniejsze o czynnik $8 \times 10^{3} \mathrm{w}$ porównaniu z tempem dyfuzji tlenu w powietrzu. Współczynnik pojemności, to jest przyrost stężenia podzielony przez przyrost ciśnienia cząstkowego tlenu w wodzie, jest 30 razy mniejszy niż w powietrzu. W wodzie nasyconej, w temperaturze $20^{\circ} \mathrm{C}, 1 \mathrm{ml}$ tlenu zawarty jest w $200 \mathrm{~g}$ wody, podczas gdy $1 \mathrm{ml}$ tlenu zawarty jest w $5 \mathrm{ml}$ powietrza (o masie $7 \mathrm{~g}$ ). W zasadzie, ze względu na większą lepkość wody niż powietrza, otrzymanie jednakowej ilości tlenu poprzez oddychanie w wodzie wymaga więcej energii. ${ }^{106}$

Większa praca wymagana do wyekstrahowania tlenu z wody stanowi główny powód, dla którego podstawowe i maksymalne tempo metabolizmu ryb jest

\footnotetext{
${ }^{105}$ Por. Denton, Nature's Destiny..., rozdz. 9.

${ }^{106}$ J.N. MaINA, ,Structure and Function and Evolution of the Gas Exchangers: Comparative Perspectives”, Journal of Anatomy 2002, vol. 201, s. 284 [281-304].
} 
6 do 10 razy wolniejsze niż tempo metabolizmu u ssaków i ptaków. ${ }^{107}$ Co więcej, kolejne ograniczenie ma związek z tym, że rozpuszczalność tlenu gwałtownie maleje wraz ze wzrostem temperatury (rozpuszczalność $\mathrm{w}$ temperaturze $30^{\circ} \mathrm{C}$ wynosi tylko połowę wartości rozpuszczalności w temperaturze $0^{\circ} \mathrm{C}{ }^{108}$ ). Jest to ograniczenie nakładane na termiczną tolerancję u organizmów oddychających w wodzie. ${ }^{109}$ Najwyraźniej wiele czynników uniemożliwia uzyskanie wysokiego tempa metabolizmu u takich organizmów. Żaden aktywny, stałocieplny organizm nie ekstrahuje tlenu $\mathrm{z}$ wody za pomocą ,skrzeli” $\mathrm{i}$ - jeśli pominiemy scenariusze rodem z science fiction — żadna inteligentna forma życia w naszym kosmosie nigdy nie będzie oddychała skrzelami!

Chociaż niska rozpuszczalność tlenu stanowi główny czynnik ograniczający organizmy oddychające w wodzie, trudno byłoby ją znacząco zwiększyć, nie stwarzając zagrożenia dla środowiska w komórce. Jak zauważa Davies, pomimo złagodzonej reaktywności tlenu cząsteczkowego w temperaturze otoczenia „Redukcyjne środowisko komórki zapewnia wiele możliwości, by tlen przeszedł nieprzewidzianą, jednowartościową redukcję", ${ }^{110}$ czego rezultatem jest powstanie wysoce niszczycielskich rodzajów reaktywnego tlenu. ${ }^{111}$ Reaktywny tlen wytwarzany jest także fotochemicznie w komórkach przez promieniowanie UVA. ${ }^{112}$ Wyrządza on różne szkody, w tym peroksydację lipidów i mutagenezę DNA, a także odgrywa rolę w starzeniu się i chorobach. ${ }^{113}$ Gdyby — przy obec-

${ }^{107}$ Por. A.F. Bennett, „Activity Metabolism of the Lower Vertebrates”, Annual Review of Physiology 1978, vol. 400, s. 448 [447-469].

${ }^{108}$ Por. Denton, Nature's Destiny..., s. 124.

${ }^{109}$ Por. T.D. Clark, E. Sandblom, G.K. Cox, S.G. Hinch, and A.P. Farrell, „Circulatory Limits to Oxygen Supply During an Acute Temperature Increase in the Chinook Salmon (Oncorhynchus tshawytscha)", AJP: Regulatory, Integrative and Comparative Physiology 2008, vol. 295(5), s. R1631-R1639, doi: 10.1152/ajpregu.90461.2008.

${ }^{110}$ K.J. Davies, „Oxidative Stress: The Paradox of Aerobic Life”, Biochemical Society Symposium 1995, vol. 61, s. 1-31.

${ }^{111}$ Por. I. FRIDOvICH, „Oxygen Toxicity: A Radical Explanation”, Journal of Experimental Biology 1998, vol. 201, s. 1203-1209; MAINA, „Structure and Function...”, s. 283.

${ }^{112}$ Por. Rothschild and Mancinelli, „Life in Extreme Environments...”.

${ }^{113}$ Por. T.P.A. Devasagayam, J.C. Tilak, K.K. Boloor, S. SaneKetaki, S.S. Ghaskadbi, and R.D. Lele, „Free Radicals and Antioxidants in Human Health: Current Status and Future Pro- 
nym poziomie tlenu $(21 \%)$ - rozpuszczalność tlenu była większa, stężenie reaktywnego tlenu w układach biologicznych byłoby najprawdopodobniej zbyt duże.

Najwyraźniej wiele cech tlenu jest subtelnie dostrojonych do organizmów oddychających powietrzem, lecz nie do organizmów ekstrahujących zasoby tlenu z wody. Oczywiście są one także zupełnie nieistotne dla żyjących w skałach skorupy ziemskiej bakterii beztlenowych i ekstremofilów, które w ogóle nie doświadczają problemów ,życia z tlenem”.

\section{Dostosowanie produktów końcowych metabolizmu do organizmów oddychających powietrzem}

Pomimo wielkiej użyteczności utleniania energia chemiczna metabolizmu tlenowego nie byłaby dostępna dla złożonych organizmów, gdyby produkty końcowe tego metabolizmu nie były nieszkodliwe i łatwe do usunięcia. Trzy z produktów końcowych tlenowego rozpadu związków węgla (por. równanie 1) to woda, $\mathrm{CO}_{2}$ i ciepto.

Woda $\boldsymbol{i} \boldsymbol{C O}_{2}$. Woda jest nie tylko nieszkodliwa, lecz stanowi też samą macierz życia. Innym produktem końcowym tlenowego rozpadu związków węgla jest $\mathrm{CO}_{2}$. Gdyby była to substancja toksyczna, gdyby nie była rozpuszczalna w wodzie, gdyby była nierozpuszczalnym ciałem stałym lub gdyby rozpuszczała się w wodzie, tworząc silny kwas, to całkowite utlenienie węgla do $\mathrm{CO}_{2}$ byłoby niemożliwe.

$\mathrm{CO}_{2}$ nie jest jednak taką substancją. Jest to względnie niereaktywny związek i w temperaturze otoczenia ma postać gazu. Ta druga cecha jest korzystna, ponieważ jest to jeden $z$ bardzo niewielu gazowych tlenków w temperaturze otoczenia. ${ }^{114}$ Co więcej, jest on w pełni utleniony i stabilny w obecności tlenu, stanowiąc kluczowy element dostosowania $\mathrm{w}$ atmosferze zawierającej $21 \%$ tlenu! Ponadto $\mathrm{CO}_{2}$ jest rozpuszczalny i z łatwością wydzielany w płucach organizmów lądowych poprzez oddychanie, czyli tą samą drogą, jaką absorbowany jest tlen.

spects", Journal of the Association of Physicians of India 2004, vol. 52, s. 794-804.

${ }^{114}$ Por. Needham, The Uniqueness of Biological Materials..., s. 35. 
Te właściwości są szczególnie użyteczne dla organizmów oddychających powietrzem. Jak wskazuje Henderson:

W ciągu dnia człowiek średniego wzrostu produkuje, w wyniku aktywnego metabolizmu, około jeden kilogram dwutlenku węgla. Cała ta ilość musi zostać szybko wydalona z organizmu. Trudno byłoby sobie wyobrazić, dzięki jakim skomplikowanym środkom chemicznym i fizycznym organizm może pozbywać się tak dużych ilości materiału, gdyby nie to, że poprzez płuca [...] [dwutlenek węgla] może wydostać się do powietrza, które zawiera niewiele tego gazu. Gdyby dwutlenek węgla nie był gazowy, jego wydalenie byłoby najtrudniejszym zadaniem fizjologicznym. Gdyby nie był łatwo rozpuszczalny, wiele najpowszechniejszych procesów fizjologicznych byłoby niemożliwych. ${ }^{115}$

Chłodzenie wody poprzez parowanie nie przynosi większych korzyści organizmom wodnym lub ekstremofilom w głębokiej, gorącej biosferze i wiele cech tlenu nie ma bezpośredniego znaczenia dla bakterii beztlenowych. Tak samo gazowa natura $\mathrm{CO}_{2}$ ma mniejsze bezpośrednie znaczenie dla wielu organizmów jednokomórkowych lub nawet złożonych wodnych kręgowców, jak ryby, o czym przekonamy się niebawem.

Ciepto. Trzeci produkt metabolizmu tlenowego, ciepło, jest koniecznym produktem wielu reakcji chemicznych, także utleniania. W umiarkowanych ilościach ciepło jest nie tylko nieszkodliwe, ale też istotne dla takich stałocieplnych organizmów jak my. Jednak nadmiar ciepła musi być eliminowany z organizmu. Złożone organizmy wielokomórkowe mogą eliminować nadmiar ciepła tylko dzięki właściwościom wody (jednego $\mathrm{z}$ dwu pozostałych produktów końcowych metabolizmu tlenowego). Umożliwia to nie tylko jedna właściwość wody. Wysoka wydajność termiczna wody zapewnia pierwszą ochronę przed wzrostem temperatury ciała, a jej niska lepkość umożliwia funkcjonowanie układu krążenia, który przenosi ciepło do skóry, gdzie szybkie ochładzanie wody drogą parowania umożliwia „wydalanie nadmiaru ciepła z organizmu”.

\section{Dostosowanie wodorowęglanowego systemu buforowego}

Większość $\mathrm{CO}_{2}$ będącego produktem końcowym metabolizmu tlenowego

\footnotetext{
${ }^{115}$ Henderson, The Fitness of the Environment..., s. 139-140.
} 
reaguje $\mathrm{z}$ wodą, tworząc słaby kwas, kwas węglowy $\left(\mathrm{H}_{2} \mathrm{CO}_{3}\right)$, który spontanicznie ulega hydrolizie, tworząc jony wodoru $\left(\mathrm{H}^{+}\right)$i aniony wodorowęglanowe $\left(\mathrm{HCO}_{3}^{-}\right)$.

woda $+\mathrm{CO}_{2}=$ kwas węglowy $=\begin{gathered}\text { jony wodoru }+ \\ \text { aniony wodorowęglanowe }\end{gathered}$

Aniony wodorowęglanowe $\left(\mathrm{HCO}_{3}^{-}\right)$będące produktem tej reakcji tworzą wraz z kwasem węglowym $\left(\mathrm{H}_{2} \mathrm{CO}_{3}\right)$ niezwykły system buforowy o dokładnie takich cechach, aby chronić organizmy, takie jak my, przed wzrostami kwasowości we krwi lub w płynach śródmiąższowych. Bufor wodorowęglanowy jest ważny dla całego ziemskiego życia opartego na węglu, ponieważ odgrywa rolę w ochronie oceanów i hydrosfery przed odchyleniami od neutralności. Ma on jednak również unikatowe cechy specjalnie dostosowane do takich złożonych organizmów oddychających powietrzem jak my. ${ }^{116}$ Henderson rozpływał się nad dostosowaniem buforu wodorowęglanowego ${ }^{117} \mathrm{i}$ wcale nie była to przesada. Dalsze badania w dwudziestym wieku potwierdziły jego zdumiewające dostosowanie, zwłaszcza do homeostazy kwasowo-zasadowej u organizmów oddychających powietrzem.

Slowo o systemach buforowych. Typowymi systemami buforowymi są systemy, w których występuje znacząca ilość słabego kwasu hialuronowego (HA) $\mathrm{i}$ jego tak zwana zasada sprzężona $\mathrm{A}^{-}$. W przypadku buforu wodorowęglanowego tym słabym kwasem jest kwas węglowy $\left(\mathrm{H}_{2} \mathrm{CO}_{3}\right)$, a podstawą sprzężoną jest anion wodorowęglanowy $\left(\mathrm{HCO}_{3}^{-}\right)$. To połączenie umożliwia odporność na zmiany pH roztworu. Gdy do roztworu dodawany jest kwas, który zwiększa stężenie jonów wodoru, jony wodoru $\mathrm{H}^{+}$reagują z zasadą sprzężoną $\mathrm{A}^{-}$, tworząc słaby kwas HA i tym samym wchłaniając nadmiar jonów wodoru i neutralizując roztwór. Gdy do roztworu dodawana jest zasada, która zmniejsza stężenie jonów wodoru, słaby kwas HA oddaje jony wodoru, to jest $\mathrm{HA}=\mathrm{H}^{+}+\mathrm{A}^{-}$, w tym wypadku także neutralizując roztwór. Zbyt duża ilość kwasu lub zasady przekroczy jednak wydajność buforu, skutkując znacznymi zmianami pH.

\footnotetext{
${ }^{116}$ Uwaga: wodorowęglan odgrywa jedynie niewielką rolę w ochronie wewnątrzkomórkowej, zarówno u organizmów wyższych, jak i u form jednokomórkowych.

${ }^{117}$ Por. Henderson, The Fitness of the Environment..., s. 153.
} 
Jak wspomniano wyżej, w przypadku wodorowęglanowego systemu buforowego słaby kwas występuje w postaci $\mathrm{H}_{2} \mathrm{CO}_{3}$, a zasadą sprzężoną jest $\mathrm{HCO}_{3}^{-}$. Stężenie wodoru (czyli pH), ${ }^{118}$ przy którym te dwie formy znajdują się w równowadze, to znaczy ich stężenie jest równe, nazywane jest „stałą dysocjacji kwasu" lub pKa.

$$
\mathrm{p} K \mathrm{a}=\mathrm{pH}, \text { gdy }\left[\mathrm{HCO}_{3}^{-}\right]=\left[\mathrm{H}_{2} \mathrm{CO}_{3}\right]
$$

pKa kwasu węglowego jest bliska 6.1 we krwi i w innych płynach w organizmie. ${ }^{119}$ Jest znacznie niższa niż rzeczywiste $\mathrm{pH}$ krwi, które wynosi 7.3. Na pierwszy rzut oka wygląda to na anomalię. Aby funkcjonować wydajnie jako bufor, stężenie kwasowych i zasadowych form buforu powinno znajdować się w równowadze (występować w równych stężeniach) na poziomie kwasowości w płynach pozakomórkowych, których $\mathrm{pH}$ wynosi około 7.4. Jednakże bufor wodorowęglanowy funkcjonuje optymalnie na poziomie $\mathrm{pH}$ równym 6.1, który jest znacznie niższy niż pH 7.4. Mogłoby się więc wydawać, że system wodorowęglanowy nie jest idealnie przystosowany do buforowania płynów w organizmie. Jest to jednak anomalia jedynie pozorna. Co zdumiewające, dzięki tej rzekomej anomalii bufor jest szczególnie dostosowany do utrzymywania homeostazy kwasowo-zasadowej u organizmów oddychających powietrzem, co stanowi kolejne świadectwo dostosowania przyrody do takich istot jak my.

Ponieważ pKa kwasu węglowego jest znacznie mniejsza od pH krwi, stężenie wodorowęglanu we krwi jest znacznie większe niż byłoby, gdyby pKa zbliżała się do wartości 7.4. W książce Clinical Physiology of Acid-Base and Electrolyte Disorders [Kliniczna fizjologia zaburzeń równowagi kwasowozasadowej i elektrolitów] Rose wskazuje, że ta anomalia „podnosi ilość dostępnego wodorowęglanu mającego wchłaniać kwas". ${ }^{120}$ Organizm dysponuje więc rezerwą zasadową do wchłaniania nadmiaru kwasu (na przykład podczas intensywnych ćwiczeń, gdy w mięśniach produkowany jest kwas mlekowy). Ta re-

\footnotetext{
${ }^{118} \mathrm{pH}$ definiowane jest jako logarytm stężenia jonów wodoru.

${ }^{119}$ Por. M. Lieberman and A.D. Marks, Marks' Basic Medical Biochemistry: A Clinical Approach, 3rd North American edition, Lippincott Williams \& Wilkins, Philadelphia 2008, s. 50-51.

${ }^{120}$ B.D. Rose, Clinical Physiology of Acid-Base and Electrolyte Disorders, McGraw Hill, New York 1977, s. 176.
} 
zerwa może być jednak wykorzystana tylko ze względu na łatwość, z jaką kwas $\mathrm{H}_{2} \mathrm{CO}_{3}$ może dysocjować do postaci wody i $\mathrm{CO}_{2}$, a także łatwość, z jaką $\mathrm{CO}_{2}$ może być wydychany $\mathrm{z}$ organizmu poprzez płuca, tworząc $\mathrm{w}$ tej reakcji produkty pokazane po prawej stronie poniższego równania 4 :

$$
\mathrm{H}^{+}+\mathrm{HCO}_{3}^{-}=\mathrm{H}_{2} \mathrm{CO}_{3}=\mathrm{CO}_{2}+\mathrm{H}_{2} \mathrm{O}
$$

Gdy podnosi się stężenie jonów wodoru w przypadku „Zwykłego buforu”, jony wodoru łączą się z zasadą, tworząc kwas, czyli $\mathrm{H}^{+}+\mathrm{A}^{-}=\mathrm{HA}$. Skoro jednak kwas nie może być eliminowany i wydalany $\mathrm{z}$ organizmu w postaci lotnego gazu (jak w przypadku kwasu węglowego), stężenie kwasu szybko wzrasta do punktu równowagi, w którym reakcja odwraca się i jony wodoru, podlegając prawu działania mas, są ekstrahowane $\mathrm{z}$ kwasu z powrotem do roztworu. W rzeczy samej, jak komentuje Rose: „obliczenia pokazują, że ze względu na łatwość, $\mathrm{z}$ jaką dwutlenek węgla (a z nim również jony wodoru) mogą być wydychane, wydajność buforowa systemu wodorowęglanowego zwiększa się o 10 do 20 razy (w porównaniu ze zwykłym buforem) i jest skuteczniejsza od «zwykłego buforu» funkcjonującego nawet w jego optymalnym $\mathrm{pH}$ ". ${ }^{121}$

Wielu autorów wypowiadało się na temat dostosowania wodorowęglanowego systemu buforowego do utrzymywania homeostazy kwasowo-zasadowej u organizmów oddychających powietrzem. Podobnie jak Henderson, ${ }^{122}$ Edsall i Wyman również są zafascynowani niezwykłą naturą tego systemu: „Połączenie kwasowości i siły buforowej $\mathrm{H}_{2} \mathrm{CO}_{3}$ z lotnością $\mathrm{CO}_{2}$ zapewnia mechanizm o niezrównanej skuteczności w utrzymywaniu pH na stałym poziomie w układach, które tak jak organizmy żywe nieustannie mają do czynienia z kwasowymi produktami metabolizmu". ${ }^{123}$

\footnotetext{
${ }^{121}$ Rose, Clinical Physiology..., s. 176.

${ }^{122}$ Por. Henderson, The Fitness of the Environment..., s. 153.

${ }^{123}$ J.T. Edsall and J. Wyman, Biophysical Chemistry, vol. 1, Academic Press, New York 1958 , s. 550

Każdy szczegół tego systemu buforowego ukazuje dalsze aspekty jego dostosowania. Weźmy na przykład sam proces hydratacji, opisany przez Edsalla i Wymana w Biophysical Chemistry (por. Edsall and J. Wyman, Biophysical Chemistry..., s. 554): „Hydratacja $\mathrm{CO}_{2}$ do postaci $\mathrm{H}_{2} \mathrm{CO}_{3}$ to proces wymagający zmiany wiązań walencyjnych. Dwa wiązania $\mathrm{C}-\mathrm{O}$ w $\mathrm{CO}_{2}$, położo-
} 
Co więcej, ze względu na lotność $\mathrm{CO}_{2}$ i łatwość, z jaką jego poziom w organizmie może być regulowany zmianami wentylacyjnymi — łatwość, z jaką można przechodzić od lewej do prawej strony równania 4 - wodorowęglanowy system buforowy zapewnia organizmom oddychającym powietrzem środki wentylacyjne umożliwiające regulowanie stężenia jonów wodoru w płynach w organizmie. Jeśli gromadzi się kwas, można zwiększyć wentylację, by wydalić kwas z organizmu poprzez płuca. Jeżeli poziom kwasu maleje, to - dzięki spowolnieniu tempa wentylacji $-\mathrm{CO}_{2}$, a tym samym kwas, może być utrzymany w organizmie!

Oznacza to, że dwa absolutnie fundamentalne, ale i odmienne, procesy fizjologiczne: (1) utrzymywanie równowagi kwasowo-zasadowej w organizmie oraz (2) wydalanie jednego z produktów końcowych metabolizmu tlenowego, $\mathrm{CO}_{2}$, zależą w sposób zasadniczy od chemicznych i fizycznych właściwości samego $\mathrm{CO}_{2}$ oraz od produktu jego hydratacji, czyli $\mathrm{HCO}_{3}^{-}$. W Nature's Destiny sytuację tę podsumowałem następująco:

Tak więc zarówno problem wydalania produktu końcowego metabolizmu weglowego, jak i problem równowagi kwasowo-zasadowej znajduja eleganckie rozwiazanie we wlaściwościach tego samego niezwyklego zwiqzku - dwutlenku węgla. Jest to rozwiqzanie o zapierającej dech w piersiach elegancji i oszczędności oparte na innym zespole wzajemnych adaptacji między sktadnikami życia. ${ }^{124}$

ne względem siebie w płaszczyźnie $180^{\circ}$ i długie na $1,15 \AA$, przekształcają się w trzy wiązania $\mathrm{C}-\mathrm{O}$ w $\mathrm{H}_{2} \mathrm{CO}_{3}$, położone względem siebie w płaszczyźnie około $120^{\circ}$ i długie na prawie $1,3 \AA$. Nie podejmiemy tutaj próby szczegółowego omówienia elektronicznych zmian wymaganych w ramach tego procesu, tym bardziej, że niewiele o nich wiadomo. Nie jest jednak zaskakujące, że taki proces powinien zajmować sporo czasu, w przeciwieństwie na przykład do procesu takiego jak hydratacja $\mathrm{NH}_{3}$ do postaci $\mathrm{NH}_{4} \mathrm{OH}$, w którym proces hydratacji obejmuje po prostu utworzenie wiązania wodorowego między niedzieloną parą elektronów w cząsteczce amoniaku". Ten wyraźnie ezoteryczny fakt, powolność hydratacji $\mathrm{CO}_{2}$, może mieć duże znaczenie fizjologiczne. Hydratacja jest znacznie powolniejsza we krwi niż w krwinkach czerwonych, zawierających enzym anhydrazy węglanowej (por. R.E. Forster and E.D. Crandall, „Time Course of Exchanges Between Red Cell and Extracellular Fluid During $\mathrm{CO}_{2}$ Uptake”, Journal of Applied Physiology 1975, vol. 38, s. 710-718). Gdyby hydratacja zachodziła momentalnie, oznaczałoby to, że kiedykolwiek poziomy $\mathrm{CO}_{2}$ we krwi lub w tkankach organizmu nagle wzrosły na skutek jakiegoś zaburzenia oddychania, mogłoby to być przyczyną śmiertelnej acydozy.

${ }^{124}$ Denton, Nature's Destiny..., s. 133. 


\section{Bufor wodorowęglanowy u ryb}

Dalszą wskazówką, że przyroda jest szczególnie dostosowana do organizmów oddychających powietrzem, nie zaś oddychających w wodzie, jest to, że bufor wodorowęglanowy nie jest nawet w przybliżeniu tak wydajny u ryb jak u ssaków. Zauważmy najpierw, że krew ryb zawiera mniej wodorowęglanu niż krew ssaków. ${ }^{125}$ Dlaczego? Jak wyjaśnia James Clairborne, ryby muszą utrzymywać wysokie tempo przepływu wody przez skrzela, aby pobrać dostateczną ilość tlenu dla swoich potrzeb metabolicznych, a ponieważ poziom $\mathrm{CO}_{2} \mathrm{w}$ naturalnych zbiornikach wodnych jest niski, więc poziom $\mathrm{CO}_{2}$ we krwi ryb jest znacznie niższy niż u ssaków (w płucach ssaków krew ma do czynienia z wysokim poziomem $\mathrm{pCO}_{2}$ [cząstkowego ciśnienia $\mathrm{CO}_{2}$ ]. W rezultacie niższy jest również poziom wodorowęglanu. ${ }^{126}$ Clairborne komentuje: „Wzrost $\mathrm{Hg}$ o $2 \mathrm{~mm}$ $\mathrm{w} \mathrm{pCO}_{2}$ ryb [...] zmieni pH o 0,18 jednostki $[\ldots]$ co oznacza $50 \%$ wzrost $\left[\mathrm{H}^{+}\right]$. Ta sama absolutna zmiana $\mathrm{pCO}_{2}$ u ludzi skutkuje jedynie zaniedbywalną zmianą o 0,01 jednostki, co oznacza w przybliżeniu $2 \%$ zmianę $\mathrm{pH}$ ". ${ }^{127}$ Jest to wyraźna wskazówka dostosowania buforu wodorowęglanowego do organizmów oddychających powietrzem, nie zaś do organizmów oddychających w wodzie.

Przekonaliśmy się już, że wysiłek oddychania jest znacznie większy u ryb niż u kręgowców oddychających powietrzem. U człowieka w spoczynku koszt oddychania wynosi $2 \%$ całkowitego zużycia tlenu, natomiast u ryb wynosi między 10 a $12 \%$ u węgorza, a u pstrąga między 19 a $25 \% .{ }^{128} \mathrm{~W}$ rezultacie, jak komentują Perry i Gilmour, „Wentylacja u ryb zależna jest głównie od wymogów ekstrahowania tlenu z ośrodka o niskiej zawartości tlenu. [Tym samym] zdolność do wykorzystywania respiracyjnej kompensacji zaburzeń równowagi kwasowo-zasadowej jest ograniczona". ${ }^{129}$ Podczas gdy istota oddychająca powie-

\footnotetext{
${ }^{125}$ Por. J.B. Claiborne, „Acid-Base Regulation”, w: D.H. Evans and J.B. Claiborne (eds.), The Physiology of Fishes, 2nd ed., CRC Press, Boca Raton, Florida 1997, s. 181 [177-198].

${ }^{126}$ Por. Claiborne, „Acid-Base Regulation...”, s. 181.

${ }^{127}$ Claiborne, „Acid-Base Regulation...”, s. 181.

${ }^{128}$ Por. G. Shelton, „The Regulation of Breathing”, w: W.S. Hoar and D.J. Randall (eds.), Fish Physiology, vol. 4, Academic Press, New York 1970, s. 304 [293-359].

${ }^{129}$ S.F. Perry and K.M. Gilmour, ,Acid-Base Balance and $\mathrm{CO}_{2}$ Excretion in Fish: Unan-
} 
trzem łatwo może wydalić kwas z organizmu (jak pokazano w równaniu 4 powyżej), u ryb koszt zwiększonej wentylacji jest ogromny ze względu na lepkość wody. Ryby nie mogą pozwolić sobie też na zmniejszoną wentylację, aby przeciwdziałać metabolicznej alkalozie, gdyż niska zawartość tlenu w wodzie doprowadziłaby do poważnej hipoksji. Ryby, takie jak niszczuka, ${ }^{130}$ które mają płuca i skrzela, mogą i wykorzystują wentylację jako środek kontroli kwasowo-zasadowej w taki sam sposób jak ssaki i radzą sobie znacznie lepiej w niedotlenionej wodzie niż organizmy oddychające skrzelami. Chociaż istnieją pewne świadectwa, że niektóre ryby w niewielkim stopniu używają wentylacji, aby kompensować odchylenia od homeostazy kwasowo-zasadowej, ${ }^{131}$ nie może być ona wykorzystana w takim stopniu jak u kręgowców oddychających powietrzem, co dyktowane jest ograniczoną możliwością ekstrahowania tlenu z wody. ${ }^{132}$

Ujmując to prostymi słowami, żadne z czynników sprawiających, że bufor wodorowęglanowy jest tak bardzo dostosowany do organizmów oddychających powietrzem, nie mogą być wykorzystane nawet przez zaawansowane stworzenia oddychające w wodzie. Dostosowanie anomalnej wartości $\mathrm{pKa}$ wodorowęglanowego systemu buforowego, duże stężenie $\mathrm{HCO}_{3}{ }^{-}$we krwi oraz wydajność związana $\mathrm{z}$ tym, że kwas $\mathrm{H}_{2} \mathrm{CO}_{3}$ łatwo da się przekształcić w nieszkodliwy gaz i wydalić $\mathrm{z}$ organizmu poprzez płuca, łącznie tworzą synergię dostosowania o niewielkim znaczeniu dla wodnych form życia.

\section{Podsumowanie}

Wiele właściwości kluczowych elementów witalnego zespołu Hendersona

swered Questions and Emerging Models”, Respiratory Physiology \& Neurobiology 2006, vol. 154, s. 199 [199-215], doi: 10.1016/j.resp.2006.04.010. Por. też K.M. Gilmour, „Gas Exchange”, w: D.H. Evans and J.B. Claiborne (eds.), The Physiology of Fishes, CRC Press, Boca Raton, Florida 1997 s. 117 [101-128].

${ }^{130}$ Por. M. Burleson, B. Shipman, and N. SMatresk, „Ventilation and Acid-Base Recovery Following Exhausting Activity in an Air-Breathing Fish”, Journal of Experimental Biology 1998, vol. 201, s. 1359-1368.

${ }^{131}$ Por. Perry and Gilmour, „Acid-Base Balance...”, s. 199.

${ }^{132}$ Por. M.S. Haswell and D.J. Randall, „The Pattern of Carbon Dioxide Excretion in the Rainbow Trout Salmo gairdneri", Journal of Experimental Biology 1978, vol. 72, s. 17-24. 
- wody, tlenu, $\mathrm{CO}_{2}, \mathrm{HCO}_{3}^{-}$- w licznych przypadkach jest dostosowanych specjalnie do organizmów stałocieplnych, które oddychają powietrzem, czyli do takich stworzeń jak my. Są to między innymi termalne właściwości wody, jej niska lepkość, gazowa natura tlenu i $\mathrm{CO}_{2} \mathrm{w}$ temperaturze otoczenia, obojętność tlenu w temperaturze otoczenia oraz bufor wodorowęglanowy $\mathrm{z}$ jego anomalną wartością $\mathrm{pKa}$ i eleganckimi środkami regulacji równowagi kwasowo-zasadowej, jakie zapewnia organizmom oddychającym powietrzem. Niektóre właściwości tych elementów witalnego zespołu są nieistotne dla innych klas organizmów lub nawet szkodliwe.

Bardzo trudno wyobrazić sobie, że mógłby istnieć podobny zespół dostosowania do zaawansowanych form życia opartego na węglu. Jeśli istnieje tylko życie bazujące na węglu, co wydaje się prawdopodobne, to projekt jakiejkolwiek aktywnej istoty ziemskiej musiałby bardzo przypominać nasz własny. W rzeczy samej, zespół właściwości wody, tlenu i $\mathrm{CO}_{2}$ łącznie nakłada tak poważne ograniczenia na projekt i funkcjonowanie układów oddechowego i sercowo-naczyniowego, że ich projekt, nawet pomijając szczegóły struktury naczyń włosowatych i pęcherzyków, da się wyprowadzić z pierwszych zasad. W przypadku złożonych organizmów o wysokim tempie metabolizmu projekty urzeczywistnione w złożonych formach życia ziemskiego to wszystko, co może istnieć. W dziedzinie życia opartego na węglu nie istnieją żadne alternatywne projekty fizjologiczne, które mogłyby osiągnąć tak wysoką aktywność metaboliczną, jaką obserwujemy u człowieka i innych organizmów wyższych.

\section{Domniemane wady i projekt}

\section{Problemy z wodą}

Krytycy argumentu na rzecz dostosowania wskazują na rzekome wady niektórych kluczowych elementów witalnego zespołu. Twierdzi się na przykład, że woda jest zbyt reaktywna, by można było uznać ją za idealnie dostosowaną, ma ona bowiem tendencję do hydrolizowania związków organicznych. Jak komentują badacze z NASA, „Reaktywność wody stwarza problemy [...] w szczególności wiele cząsteczek jest niestabilnych w wodzie [...] ich zastąpienie wymaga 
więc dodatkowej reakcji metabolicznej”. ${ }^{133}$ Oto inny ich komentarz: „Woda reaguje $\mathrm{z}$ wieloma cząsteczkami biologicznymi w sposób, który prowadzi do ich uszkodzenia [...] Ta niekorzystna reaktywność wody jest szczególnie ewidentna w przypadku RNA i DNA, ponieważ w wodzie zasady tracą grupy aminowe, co skutkuje utratą informacji genetycznej”. ${ }^{134} \mathrm{~W}$ innej części, zatytułowanej „The Reactivity of Water Constrains Routes to Origins" [Reaktywność wody ogranicza drogi do powstania życia], zwracają uwagę, że „Tworzenie biopolimerów i nukleozydów ze składowych cukrów i zasad azotowych nukleotydów, tworzenie nukleotydów z nukleozydów i fosforanów [oraz] oligonukleotydów z nukleotydów zachodzi w wodzie w sposób odwrotny do działania procesów termodynamicznych". ${ }^{135}$ To samo dotyczy tworzenia białek z aminokwasów.

Tendencja wody do degradowania złożonych cząsteczek organicznych nazywana jest przez badaczy z NASA ,przeszkodą” na drodze do powstania życia. Zgadzają się z tym także inni badacze. Zespół Bennera komentuje: „Toksyczność wody stwarza szczególne problemy dla chemii prebiotycznej, gdyż mechanizmy naprawcze przypuszczalnie wymagają istnienia jakiegoś układu ożywionego". ${ }^{136}$ Innymi słowy, właściwości wody nie sa dostosowane do powstania zycia $\mathrm{w}$ takiej postaci, jakie zgodnie $\mathrm{z}$ wyobrażeniami tych badaczy powinno istnieć w ośrodku wodnym. Badacze z NASA wskazują też, że podwójne wiązanie węglowo-azotowe jest niestabilne w wodzie i nie może być łatwo wykorzystywane przez formy życia zależne od macierzy wodnej. ${ }^{137} \mathrm{Za}$ defekt uznają oni również tendencję wody do rozrywania wiązań wodorowych, wskazując, że „Zdolność wody do tworzenia silnych wiązań wodorowych prowadzi do rozrywania wiązań wodorowych użytecznych w przypadku struktur supramolekular-

\footnotetext{
s. 16.

${ }^{133}$ Baross, Benner, Cody, Copley, Pace, Scott, and Shapiro, The Limits of Organic Life...,

${ }^{134}$ Baross, Benner, Cody, Copley, Pace, Scott, and Shapiro, The Limits of Organic Life..., s. 27. s. 60 .

${ }^{135}$ Baross, Benner, Cody, Copley, Pace, Scott, and Shapiro, The Limits of Organic Life...,

${ }^{136}$ Benner, Ricardo, and Carrigan, „Is There a Common Chemical Model...”, s. 681.

${ }^{137}$ Por. Baross, Benner, Cody, Copley, Pace, Scott, and Shapiro, The Limits of Organic Life..., s. 70 .
} 
nych". ${ }^{138} \mathrm{~W}$ związku z tym chemicy badający układy samoorganizujące się mają skłonność do pomijania wody w swoich scenariuszach, gdyż „rozrywa ona kierunkowe wiązania niekowalencyjne, takie jak wiązania wodorowe”. ${ }^{139}$

Ci sami autorzy argumentują ponadto, ${ }^{140}$ że chociaż znany nam ziemski lód (lód 1) ma mniejszą gęstość niż woda i unosi się na niej, inne formy lodu tworzone pod bardzo dużymi ciśnieniami, być może na planetach masywniejszych od Ziemi (lód 2 i inne formy lodu), są w istocie cięższe od wody. Przyznają oni, że lód tworzący się na Ziemi (lód 1) jest korzystny dla życia, ponieważ pod unoszącym się lodem woda pozostaje w stanie ciekłym, ale dla nich większe albedo (współczynnik odbicia) lodu w porównaniu $\mathrm{z}$ albedo wody jest defektem, który mógł przyczyniać się do epok lodowcowych wielokrotnie powtarzających się w historii Ziemi.

„Problem” z większością tych wad, pomijając większe albedo lodu w porównaniu $\mathrm{z}$ albedo wody (wada trudna do oceny ze względu na ogromną złożoność modelowania klimatu), polega na tym, że niemal wszystkie stanowią ,przeszkodę na drodze do powstania życia”. ${ }^{141}$ Reaktywność wody i jej aktywność hydrolityczna poważnie utrudniają zrozumienie, w jaki sposób forma życia opartego na węglu mogła powstać w wodzie przy braku maszynerii syntetycznej współczesnych komórek. Skoro jednak droga do powstania życia nie jest zrozumiana i zważywszy na to, że hydrolityczna aktywność wody prawdopodobnie odgrywa ważną rolę w przekształcaniu materii we wszystkie komórki - co jest przyznawane przez badaczy z NASA ${ }^{142}$ - trudno postrzegać te wady jako po-

\footnotetext{
${ }^{138}$ Baross, Benner, Cody, Copley, Pace, Scott, and Shapiro, The Limits of Organic Life..., s. 70 . s. 70.

${ }^{139}$ Baross, Benner, Cody, Copley, Pace, Scott, and Shapiro, The Limits of Organic Life...,

${ }^{140}$ Por. Baross, Benner, Cody, Copley, Pace, Scott, and Shapiro, The Limits of Organic Life..., s. 69 .

${ }^{141}$ Baross, Benner, Cody, Copley, Pace, Scott, and Shapiro, The Limits of Organic Life..., s. 60 .

${ }^{142}$ Por. Baross, Benner, Cody, Copley, Pace, Scott, and Shapiro, The Limits of Organic Life..., s. 27.
} 
ważne zagrożenie dla tezy o dostosowaniu wody do życia istniejącego na Ziemi obecnie.

\section{Problemy z tlenem}

Wielu autorów zwracało uwagę na potencjalne zagrożenie stwarzane przez tlen życiu bazującemu na węglu ze względu na to, że tlen jest reaktywny, istnieją też wysoce niszczycielskie rodzaje reaktywnego tlenu, a stąd wynika konieczność ochrony antyoksydacyjnej. ${ }^{143}$ Krytycy argumentu na rzecz dostosowania równie dobrze mogą wskazywać na reaktywność tlenu jako główny defekt w przyrodzie. Jak komentuje Maina:

Ataki reaktywnego tlenu na DNA, białka i inne makrocząsteczki są przemożne. Obliczono na przykład, że około 2-3\% tlenu przejmowanego przez komórki tlenowe tworzy rodnik $\mathrm{O}_{2}^{-}$[anionorodnik ponadtlenkowy] oraz $\mathrm{H}_{2} \mathrm{O}_{2}$ [nadtlenek wodoru]; ${ }^{144}$ komórka szczura przyjmuje około $10^{12}$ cząsteczek tlenu dziennie, generując około $2 \times 10^{10}$ (to jest $2 \%$ ) $\mathrm{O}_{2}^{-}{ }^{-} \mathrm{H}_{2} \mathrm{O}_{2}$; w komórce szczura dochodzi do około $9 \times 10^{4}$ ataków na DNA dziennie; ${ }^{145}$ codziennie reaktywny tlen odpowiada za około 10000 modyfikacji zasad DNA w komórce. ${ }^{146}$

Współczesne komórki skutecznie bronią się przed tymi reaktywnymi produktami za pomocą antyoksydacyjnych metaloenzymów, jak dysmutazy ponadtlenkowe, katalazy i peroksydazy. Enzymy te sa nieodzowne dla adaptacji wszystkich komórek żywych do użytkowania tlenu. ${ }^{147} \mathrm{~W}$ pewnych przypadkach

\footnotetext{
${ }^{143}$ Por. Benner, Ricardo, and Carrigan, „Is There a Common Chemical Model...”; Maina, „Comparative Respiratory Morphology...”; Clark, Sandblom, Cox, Hinch, and Farrell, „Circulatory Limits to Oxygen Supply...”; DAVIES, „Oxidative Stress...”.

${ }^{144}$ Por. też B. Chance, H. Sies, and A. Boveris, „Hydroperoxide Metabolism in Mammalian Organs", Physiological Reviews 1979, vol. 59, s. 527-605.

${ }^{145}$ Por. też C.G. Fraga, M.K. Shigenaga, J.W. Park, P. Degan, and B.N. Ames, „Oxidative Damage to DNA During Aging: 8-Hydroxy-2'-Deoxyguanosine in Rat Organ DNA and Urine", Proceedings of the National Academy of Sciences USA 1990, vol. 87, s. 4533-4537, doi: 10.1073/ pnas.87.12.4533.

${ }^{146}$ Maina, „Structure and Function...”, s. 283. Por. też B.N. Ames, M.K. Shigenaga, and L.S. Gold, „DNA Lesions, Inducible DNA Repair, and Cell Division: Three Key Factors in Mutagenesis and Carcinogenesis", Environmental Health Perspectives 1993, vol. 101, Suppl. 5, s. 35-44.

${ }^{147}$ Por. Devasagayam, Tilak, Boloor, SaneKetaki, Ghaskadbi, and Lele, „Free Radicals and
} 
są one nadzwyczaj skuteczne, ${ }^{148}$ dzięki czemu istniejące organizmy są w stanie przetrwać i w istocie świetnie prosperują w obecności tlenu. Niektóre drzewa mogą żyć kilka tysięcy lat, ${ }^{149}$ małże kilkaset lat, ${ }^{150}$ a żółwie ponad sto lat. ${ }^{151}$ Metale przejściowe potrafią skutecznie łagodzić reaktywność tlenu, zaś złożone organizmy mogą czerpać energię z utleniania i świetnie prosperować. W rzeczy samej, pewne formy życia, na przykład płazińce ${ }^{152}$ oraz meduzy Turritopsis, ${ }^{153}$ mogą być nawet nieśmiertelne, co wskazuje, że przynajmniej w niektórych przypadkach uszkodzenia wywoływane przez wolne rodniki u istniejacych form życia, chronionych obecnie przez baterię enzymów antyoksydacyjnych, nie mają żadnych dtugoterminowych szkodliwych skutków.

Oczywiście, podobnie jak reaktywność wody stanowi przeszkodę na drodze do powstania życia, tak reaktywność tlenu utrudnia zrozumienie, jak sinice, które nie dysponowały zespołem enzymów antyoksydacyjnych, mogły podejmować próby wykorzystania lub produkowania tak niebezpiecznego pierwiastka. Problem, z jakim musiały mierzyć się wszystkie pierwotne organizmy usiłujące wykorzystać tlenową fotosyntezę bez ochrony enzymów zdolnych do degradowania reaktywnych rodzajów tlenu, jest ewidentny, ale nie można uznać tego za świadectwo, że przyroda nie jest dostosowana do ludzi lub że tlen nie jest dostosowany do życia istniejacego na Ziemi.

Antioxidants in Human Health...”.

${ }^{148}$ Por. Fridovich, „Oxygen Toxicity...”.

${ }^{149}$ Por. R.M. Lanner, The Bristlecone Book: A Natural History of the World's Oldest Trees, Mountain Press Pub. Co., Missoula, Montana 2007, s. 2.

${ }^{150}$ Por. E.E.R. Philipp and D. Abele, „Masters of Longevity: Lessons from Long-Lived Bivalves - A Mini-Review", Gerontology 2010, vol. 56, s. 55-65, doi: 10.1159/000221004.

${ }^{151}$ Por. P. Chambers, „The Origin of Harriet”, New Scientist 2004, vol. 183, s. 38-42.

${ }^{152}$ Por. T.C.J. Tan, R. Rahman, F. Jaber-Hijazi, D.A. Felix, C. Chen, E.J. Louis, and A. AbooBAKER, „Telomere Maintenance and Telomerase Activity Are Differentially Regulated in Asexual and Sexual Worms", Proceedings of the National Academy of Sciences USA 2012, vol. 109, s. 4209-4214, doi: 10.1073/pnas.1118885109.

${ }^{153}$ Por. S.F. Gilbert, Developmental Biology, 9th ed., Sinauer Associates, Sunderland, Massachusetts 2010, rozdz. 2 . 
Innym możliwym „defektem” może być bardzo powolna hydratacja $\mathrm{CO}_{2} .{ }^{154}$ Chociaż może to być kluczowa adaptacja, która zapobiega nagłym zmianom kwasowości przy wzroście poziomu $\mathrm{CO}_{2}$ we krwi, jest ona powolna na tyle, że czas potrzebny do pełnego zrównoważenia jest, jak wskazuje Albers, „200 razy dłuższy niż czas przebywania $\left[\mathrm{CO}_{2}\right]$ w skrzelach lub w płucach". ${ }^{155}$ Zważywszy, że $\mathrm{CO}_{2}$ transportowany jest $\mathrm{w}$ formie wodorowęglanu, mogłoby to wydawać się przeszkodą w wydalaniu $\mathrm{CO}_{2}$ poprzez płuca. Organizmy potrafią przezwyciężyć tę trudność, ponieważ ich krwinki czerwone (oraz skrzela ryb) zawierają enzym anhydrazę węglanową, który katalizuje reakcję i przekształca $\mathrm{CO}_{2} \mathrm{w}$ wodorowęglan w tkankach, a wodorowęglan w $\mathrm{CO}_{2}$ w płucach.

Sagan, krytykując model antropocentryczny, wypowiedział słynne słowa: „Nasz Wszechświat prawie nie dopuszcza możliwości powstania życia. Nawet gdyby każda gwiazda w stu miliardach galaktyk miała podobną do Ziemi planetę, to [...] życie byłoby możliwe jedynie w obrębie $10^{-37}$ całkowitej objętości Wszechświata". ${ }^{156}$ Jednak twierdzenie, że prawa przyrody są wyjątkowo dostosowane do ludzi, nie jest negowane przez to, że nie możemy żyć w każdej części powierzchni planety lub w każdym zakątku przestrzeni kosmicznej. Istnienie wulkanów, arktycznych czap lodowych czy głębin oceanicznych, to jest habitatów nieprzyjaznych dla ludzi, nie ma żadnego wpływu na przedstawioną w tym artykule argumentację. Jedynym sposobem wykazania, że kosmos nie jest wyjątkowo (czy wyłącznie) dostosowany do życia istniejącego na Ziemi i do zaawansowanych jego form, takich jak my, jest pokazanie, że kosmos jest dostosowany do kosmitów rodem z filmu Star Trek lub do alternatywnej biochemii.

\section{Wnioskowanie o projekcie}

Czy możemy dojść do wniosku, że antropocentryczne subtelne zestrojenie jest wynikiem inteligentnego projektu? Chociaż nigdzie w The Fitness Henderson nie idzie za Wallacem i nie opowiada się za teorią inteligentnego projektu,

\footnotetext{
${ }^{154}$ Por. przyp. 123.

${ }^{155}$ C. Albers, „Acid-Base Balance”, w: W.S. Hoar and D.J. Randall (eds.), Fish Physiology, Academic Press, New York 1970, s. 173-208.

${ }^{156}$ SAGAN, Błękitna kropka..., s. 56 przyp. 5.
} 
niektóre jego twierdzenia - na przykład, że wyjątkowy zespót ukazuje „niezrównane dostosowanie” czy „największe możliwe dostosowanie” lub że nie ujawnia ,ani jednej ułomności” - przywodzą na myśl wnioskowanie o projekcie. ${ }^{157}$ Twierdzenia te nie są jednak zupełnie przekonujące. Jak wiemy, nie wszystkie właściwości zespołu Hendersona są maksymalnie dostosowane do wszystkich rodzajów życia. Jednym z wyżej omawianych przykładów jest niska rozpuszczalność tlenu w wodzie, która jest wyraźnie niekorzystna dla dużych organizmów wodnych oddychających w wodzie i czerpiących energię z metabolizmu tlenowego. Także hydratacja $\mathrm{CO}_{2}$ jest tak powolna, że wymaga enzymu anhydrazy węglanowej, aby zapewnić prawidłowe wydalanie i wchłanianie $\mathrm{CO}_{2}$ (por. powyżej). Dwa inne przykłady, niewspomniane wcześniej, to fakt, że maksymalna wchłanialność chlorofilu nie jest zbieżna z maksymalną energią promieniowania Słońca, ${ }^{158}$ oraz to, że część szkodliwego promieniowania UV dociera do powierzchni Ziemi. Wreszcie, o czym była mowa wyżej, wolne rodniki powodują choroby.

Niemniej, pomimo tych dostrzegalnych defektów trudno nie zdumiewać się tym, że właściwości elementów witalnego zespołu są szczególnie dostosowane do życia istniejącego na Ziemi w niezwykle synergiczny i oszczędny sposób. Na przykład wszystkie te elementy są dostosowane nie tylko pod jednym, lecz pod wieloma względami. Woda jest nie tylko dostosowana do pełnienia roli macierzy komórki, ale i, ze względu na swoją niską lepkość, do układu krążenia organizmów wyższych. Jej właściwości termalne są dostosowane do homeostazy u organizmów stałocieplnych, jak również do łagodzenia klimatu planety. Podobnie, $\mathrm{CO}_{2}$ jest dostosowany do rozprowadzania atomów węgla w biosferze i jednocześnie do pomocy w utrzymywaniu równowagi kwasowo-zasadowej hydrosfery w zakresie odpowiednim dla życia.

Hendersona również fascynowała ta sama wspaniała synergia i oszczędność, dzięki której każdy związek pełni kilka różnych funkcji. Jego entuzjazm był jeszcze większy, gdy dostrzegł, że woda i $\mathrm{CO}_{2}$ są nie tylko fizycznie dostosowane pod wieloma względami do życia opartego na węglu, ale też zbudowane są

\footnotetext{
${ }^{157}$ Por. odpowiednio: Henderson, The Fitness of the Environment..., s. 266, 272, 267.

${ }^{158}$ Por. M. Chen and R.E. Blankenship, „Expanding the Solar Spectrum Used by Photosynthesis”, Trends in Plant Science 2011, vol. 16, s. 427-431, doi: 10.1016/j.tplants.2011.03.011.
} 
$\mathrm{z}$ trzech atomów tworzących łącznie uniwersum organicznych substancji chemicznych, materialną podstawę wszystkich istot żywych. ${ }^{159}$ Ta sama grupa atomów, która jest wyjątkowo dostosowana do tworzenia złożonej molekularnej struktury istot żywych (białek, DNA i tak dalej), jest także szczególnie dostosowana do tworzenia idealnej macierzy i idealnego buforu, które umożliwiają istnienie tych samych „form życia”. Jak już się przekonaliśmy, w odniesieniu do utleniania Henderson komentuje, że „Te same zmiany chemiczne, które z wielu innych powodów wydają się najlepiej dostosowane do przeobrażenia się w procesy fizjologiczne, okazują się również tymi, które mogą zmienić największy napływ energii w strumień życia". ${ }^{160}$

Jedne z najbardziej uderzających przykładów synergii i oszczędności pośród właściwości elementów zespołu, tych, które sprawiają, że przyroda jest dostosowana do „zwierzęcia, takiego jak człowiek”, związane są z właściwościami stanowiącymi podstawę zdolności do wykorzystywania energii utleniania. Po pierwsze, tlen i $\mathrm{CO}_{2}$ są gazami w temperaturach, w których woda znajduje się w stanie ciekłym. Po drugie, dwa chemiczne produkty końcowe metabolizmu tlenowego, woda i $\mathrm{CO}_{2}$, reagują ze sobą chemicznie, tworząc bufor wodorowęglano$w y$, który ma idealne cechy do buforowania płynów organizmów oddychających powietrzem. Po trzecie, związek chemiczny tworzący ten bufor $\left(\mathrm{HCO}_{3}{ }^{-}\right)$używany jest do transportowania $\mathrm{CO}_{2}$ do płuc. Po czwarte, ciekła woda nie tylko reaguje chemicznie $\mathrm{z} \mathrm{CO}_{2}$, tworząc $\mathrm{HCO}_{3}^{-}$, ale i fizycznie transportuje go do płuc, co zależne jest od niskiej lepkości wody. (Jak omówiono wyżej, projekt układu krążenia jest kategorycznie zależny od tej właściwości wody.) Po piąte, woda, z racji swojej wysokiej wydajności cieplnej, wchłania nadmiar ciepła (trzeci produkt końcowy metabolizmu tlenowego), a także transportuje go do peryferii organizmu, gdzie jej wysokie, utajone ciepło parowania w wielkiej mierze wspomaga chłodzenie ciała. To, że oddychanie u organizmów wyższych powinno zależeć od tak wyjątkowo pięknej synergii oraz oszczędności fizycznych i chemicznych właściwości zaangażowanych w ten proces kluczowych związków, w pełni podlega wnioskowaniu o inteligentnym projekcie. Można odpowiednio sparafrazować słowa Hoyle'a: „Zdroworozsądkowa interpretacja fak-

\footnotetext{
${ }^{159}$ Por. Henderson, The Fitness of the Environment..., s. 220.

${ }^{160}$ Henderson, The Fitness of the Environment..., s. 247.
} 
tów sugeruje, że jakiś super intelekt manipulował prawami chemicznymi i biologicznymi tak, by osiągnąć szczególny cel, jakim są takie organizmy jak my”.

\section{Zakończenie}

Istnieje niewiele książek, które przetrwały próbę czasu w tak wielkim stopniu jak The Fitness Hendersona. Dalsze badania w chemii, biologii molekularnej, fizjologii i innych dyscyplinach nauk podstawowych w dwudziestym wie$\mathrm{ku}$, aż po dzień dzisiejszy, w dużej mierze potwierdziły twierdzenie Hendersona, że kosmos jest wyjątkowo dostosowany do życia istniejącego na Ziemi i do „Zwierzęcia, takiego jak człowiek”. Niemal każde odkrycie w dwudziestowiecznej biochemii i kosmologii potwierdza pogląd, którego w tak jasny sposób bronił on jako pierwszy. Poszukując życia w kosmosie, NASA szuka wody i form życia opartego na węglu. W przypadku oznak inteligentnego życia poszukiwany jest zaś tlen. Rzekome „wady” niektórych kluczowych substancji biochemicznych mogą stanowić wyzwanie dla poglądu, że wszystkie prawa przyrody są doskonale dostosowane do wszystkich typów życia bazującego na węglu. Nie podważają one jednak ani twierdzenia, że kosmos jest wyjątkowo dostosowany do życia opartego na węglu, ani antropocentrycznej tezy, że przyroda jest szczególnie dostosowana do istot o naszej konstytucji biologicznej i projekcie fizjologicznym.

Zwróćmy wreszcie uwagę na jeden z niewątpliwie najbardziej intrygujących paradoksów w historii nauki. Otóż okres pięćdziesięciu lat od publikacji O powstawaniu gatunków w 1859 roku do początku I Wojny Światowej, kiedy to stary teleologiczny paradygmat antropocentryczny wygasał w kulturze głównego nurtu wskutek rewolucji darwinowskiej, to również okres, w którym zaczęły pojawiać się nowe biochemiczne świadectwa naszej wyjątkowości. W tym samym czasie, gdy Nietzsche wypowiedział słynne słowa: „I oto już jest nihilizm”, ${ }^{161}$ nowe, niedocenione w tamtym czasie, odkrycia w chemii organicznej i biochemii dostarczały pierwszych wskazówek, że życie na Ziemi może być

\footnotetext{
${ }^{161}$ F. Nietzsche, Wola mocy. Próba przemiany wszystkich wartości, przeł. Stefan Frycz i Konrad Drzewiecki, Nakład Jakóba Mortkowicza, Warszawa 1910-1911, s. 32.
} 
ostatecznie rezultatem projektu, a nie szczęśliwym produktem przypadkowych zdarzeń zachodzących w długim okresie czasu, jak coraz częściej przyjmowano.

\section{Podziękowania}

Chciałbym podziękować Chuckowi Harperowi i Ann Gauger za pomoc w edycji artykułu. Bardzo staranne poprawki edytorskie Ann na ostatnich etapach przygotowania tekstu w wielkiej mierze pomogły go udoskonalić. Chciałbym również podziękować Discovery Institute za finansowe wsparcie badań, których wyniki przedstawiono w tym artykule.

Michael J. Denton

The Place of Life and Man in Nature: Defending the Anthropocentric Thesis

\section{Summary}

Here I review the claim that the order of nature is uniquely suitable for life as it exists on earth (Terran life), and specifically for living beings similar to modern humans. I reassess Henderson's claim from The Fitness of the Environment that the ensemble of core biochemicals that make up Terran life possess a unique synergistic fitness for the assembly of the complex chemical systems characteristic of life. I show that Henderson's analysis is still remarkably consistent with the facts one century after it was written. It is still widely accepted even among researchers in astrobiology. I also review the evidence for believing that many of the properties of the same core set of biochemicals are specifically fit for the physiology of complex terrestrial beings resembling modern humans. I show that none of the recent advances in the field of extremophile biology, alternative biochemistries, or recent allusions to apparent defects in the fitness of nature for Terran life significantly undermine the core argument, that nature is peculiarly fit for carbon-based Terran life, and especially for the physiology of complex terrestrial beings resembling modern humans.

Keywords: Lawrence Henderson, fitness of the environment, vital ensemble, water, oxygen, carbon dioxide, bicarbonate buffer, metabolism, biocentricity of nature, anthropocentric fine-tuning, design inference.

Słowa kluczowe: Lawrence Henderson, dostosowanie środowiska, witalny zespót, woda, tlen, dwutlenek węgla, bufor wodorowęglanowy, metabolizm, biocentryczność przyrody, antropocentryczne subtelne zestrojenie, wnioskowanie o projekcie. 